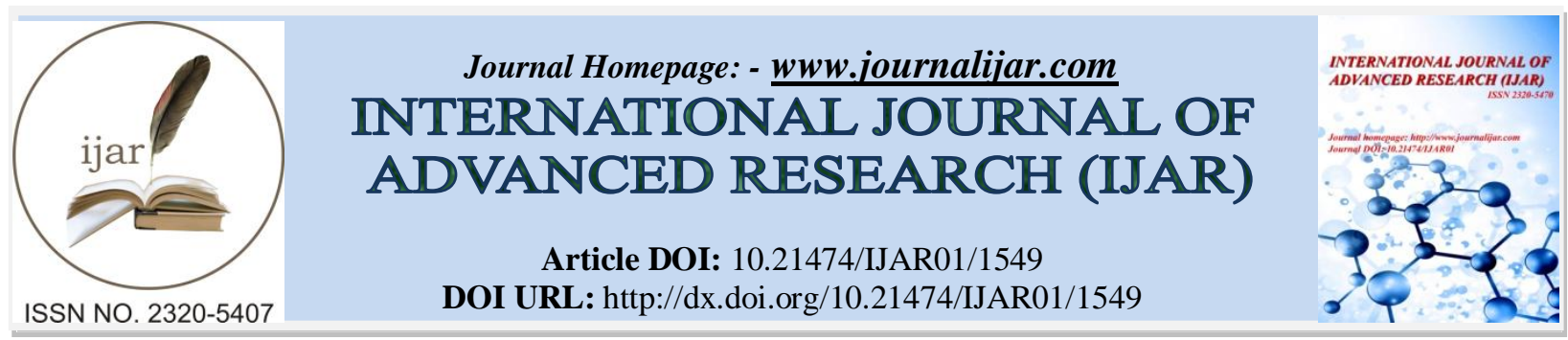

RESEARCH ARTICLE

\title{
A QUANTITATIVE ANALYSIS OF VLF DATA FOR GROUNDWATER EXPLORATION IN A HARDROCK TERRAIN IN OSMANIA UNIVERSITY CAMPUS, HYDERABAD, TELANGANA STATE, INDIA.
}

\author{
Dubba Vijay Kumar ${ }^{*}$, G. Ramadass and S.V. Jagadish. \\ Department of Geophysics, osmania University, Hyderabad.
}

\section{Manuscript Info}

Manuscript History

Received: 14 July 2016

Final Accepted: 16 August 2016

Published: September 2016

Key words:-

Very Low Frequency Electromagnetic Method (VLF-EM); Aquifer zones;

Pseudo-section; Conductivity;

Groundwater.

\section{Abstract}

Groundwater exploration is reported in the hardrock terrain of Osmania University Campus, Hyderabad area, $\left(78^{0} 31^{\prime} 00^{\prime \prime}\right.$ E Longitude to $78^{0} 32^{\prime} 30^{\prime \prime} \mathrm{E}$ Longitude and $17^{\circ} 23^{\prime} 48^{\prime \prime} \mathrm{N}$ Latitude to $17^{\circ} 25^{\prime} 42^{\prime \prime} \mathrm{N}$ Latitude) Telangana State. Nineteen (19) VLF traverses were conducted with $10 \mathrm{~m}$ interval. VLF-EM is carried out using ABEM WADI equipment to locate the spatial location of the aquifer zones like fractures, faults, dykes and EM Conductors. Applications of Fraser filter for the real and imaginary components are aided in filtering the noise and refining the raw data for location of conductive zones. A Karous Hjelt filter pseudo section reveals the nature of conductive, dip and depth of these conductors and shallow linear conductors are mapped and also identified 52, subsurface fractures which are highly groundwater potential zones.

Copy Right, IJAR, 2016,. All rights reserved.

\section{Introduction:-}

Very Low Frequency Electromagnetic (VLF-EM) method of geophysics utilizes very low frequency radio signals determine electrical properties of near surface and shallow bedrock features. This method is especially used for mapping steeply dipping structures such as faults, fractures and aquifer zones.

VLF method is a passive method that uses radiation from ground based military radio transmitters has the primary EM field for geophysical survey, utilizes signals from the communication stations operating in 3 to $30 \mathrm{KHz}$ frequency range. These stations located around the world transmit the signals. These transmitters generate plane EM waves that can induce secondary eddy currents particularly to electrically conductive elongated two dimensional targets. EM wave propagates through the subsurface and subject to local distortions by the conductivity contacts in this medium. These variations indicate the variation in geo-electrical properties which may be related to the presence of groundwater (Satpathy, B.N. and Kanungo, B.N. 1976 ${ }^{[1]}$ ). And also VLF method effectively applicable for studies for mapping contaminated zones, soil engineering, cultural detection, ionospheric, archeological and mineral exploration.

The theory and practice of VLF method is well documented by many authors (Omosuyi et al., 2008 ${ }^{[2]}$; Oluwafemi and Oladunjoye, 2013 ${ }^{[3]}$; Hazel, J.R.T., Cratchley, C.R. and Preston, A.M.1988 ${ }^{[4]}$; Paterson and Ronka $1971^{[5]}$; Pedersen, 2002 ${ }^{[6]}$; and Sundararajan et. al., $1996^{[7]}$ ).

Corresponding Author:- Dubba Vijay Kumar.

Address:- Department of Geophysics, osmania University, Hyderabad. 
The present paper reports the result of the VLF-EM surveys carried out in Osmania University campus area, Telangana State are locating groundwater potential zones.

\section{Geology:-}

The Osmania University Campus $\left(78^{0} 31^{\prime} 00^{\prime \prime} \mathrm{E}\right.$ Longitude to $78^{0} 32^{\prime} 30^{\prime \prime}$ E Longitude and $17^{0} 23^{\prime} 48^{\prime \prime} \mathrm{N}$ Latitude to $17^{0}$ $25^{\prime} 42^{\prime \prime} \mathrm{N}$ Latitude) is situated in an area of approximately 6.58 sq. km (1627.32 acres) lies in Hyderabad metro politon city (SOI). The maximum elevation observed is $535 \mathrm{~m}$ and minimum elevation is $503 \mathrm{~m}$ with respect to mean sea level. Here three types of granites exist-pink, grey and the leucogranites (Balakrishana and Rao, 1961 ${ }^{[8]}$; Sitaramayya, $1968^{[9]}, 1971^{[10]}$ ) and some pegmatite patches traversed by narrow white apatite veins, which intersect each other randomly. The granitic host rocks are (Figure: 1) intruded at places with doleritic dykes. The general geological section consists of soil layer underlain by weathered rock, which is in turn followed by the fractured rock at a few places. The basement, occurring at an average depth of $15 \mathrm{~m}$ consists of hard impervious granite. Groundwater occurence in the hardrock terrain can be vary irregular due to abrupt discontinuity in lithology, thickness and electrical properties of the overburden and weathered bedrock (Udaya Laxmi and Ramadass $2013^{[11]}$ ).

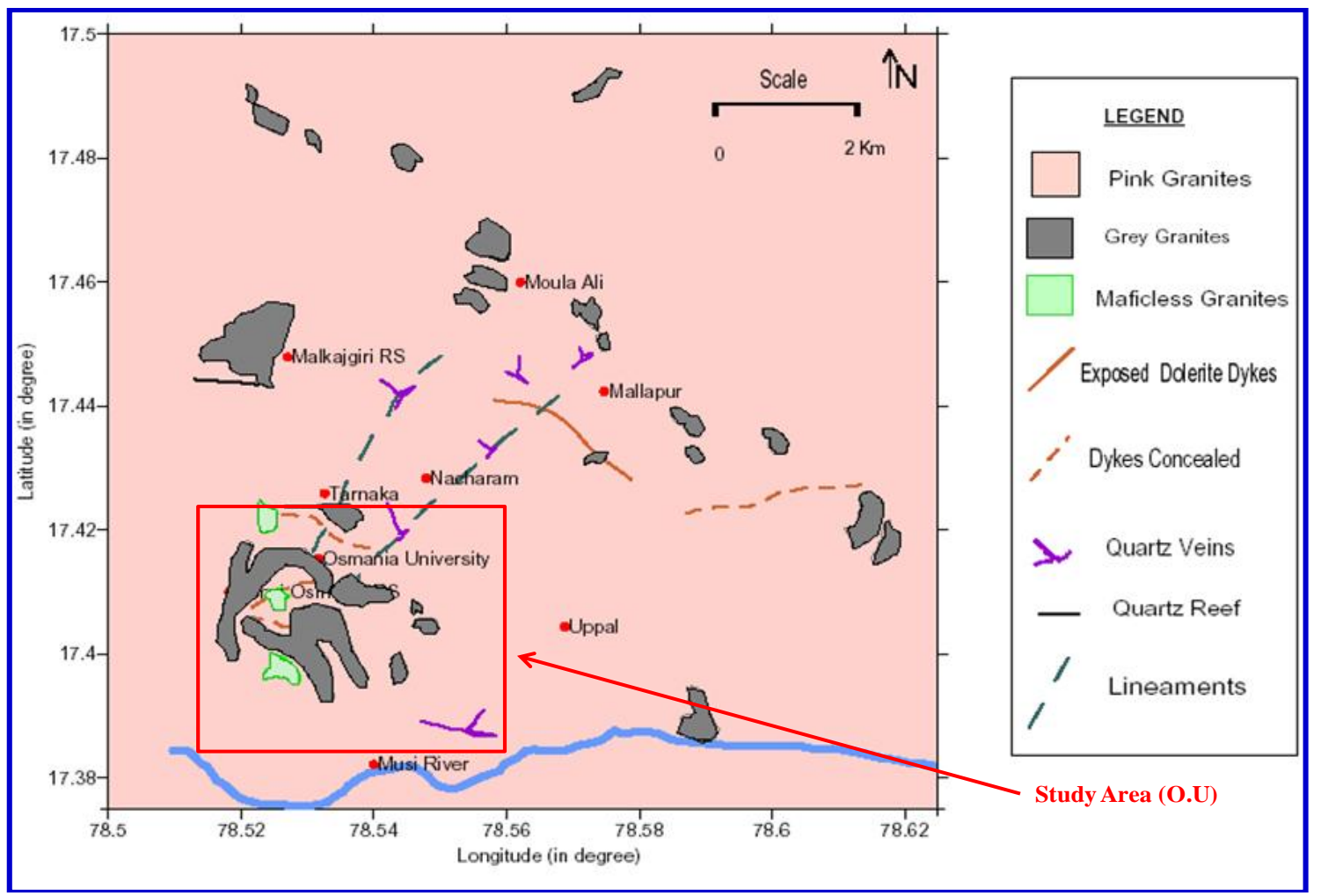

Figure 1:- Geology Map of the Study Area (After G. Udayalaxmi, 2009)

\section{Data base:-}

Electrical, VLF (Very Low Frequency) Electromagnetic and Magnetic investigations were conducted to identifying the groundwater potential zones. These studies were then supplemented by hydrogeological data to evolve an integrated exploration strategy for groundwater. The studies as investigated thus combined reconnaissance, semidetailed and detailed investigations. These integrated geophysical studies corresponding to a part of the map, were carried out roughly in comprising the Osmania University campus area (Figure: 2 ), $78^{0} 31^{\prime} 00^{\prime}$ 'E longitude to $78^{0} 32^{\prime} 26^{\prime \prime} \mathrm{E}$ longitude and $17^{0} 23^{\prime} 45^{\prime}$ ' $\mathrm{N}$ latitude to $17^{\circ} 25^{\prime} 42^{\prime}$ ' $\mathrm{N}$ latitude total area of 6.58 square kilometers (1627.32 acres). The surveys were directed towards tracing out and verifying the detailed geological setting and identifying different tectonic structures in the area which could have a definite bearing potential zones for groundwater. 


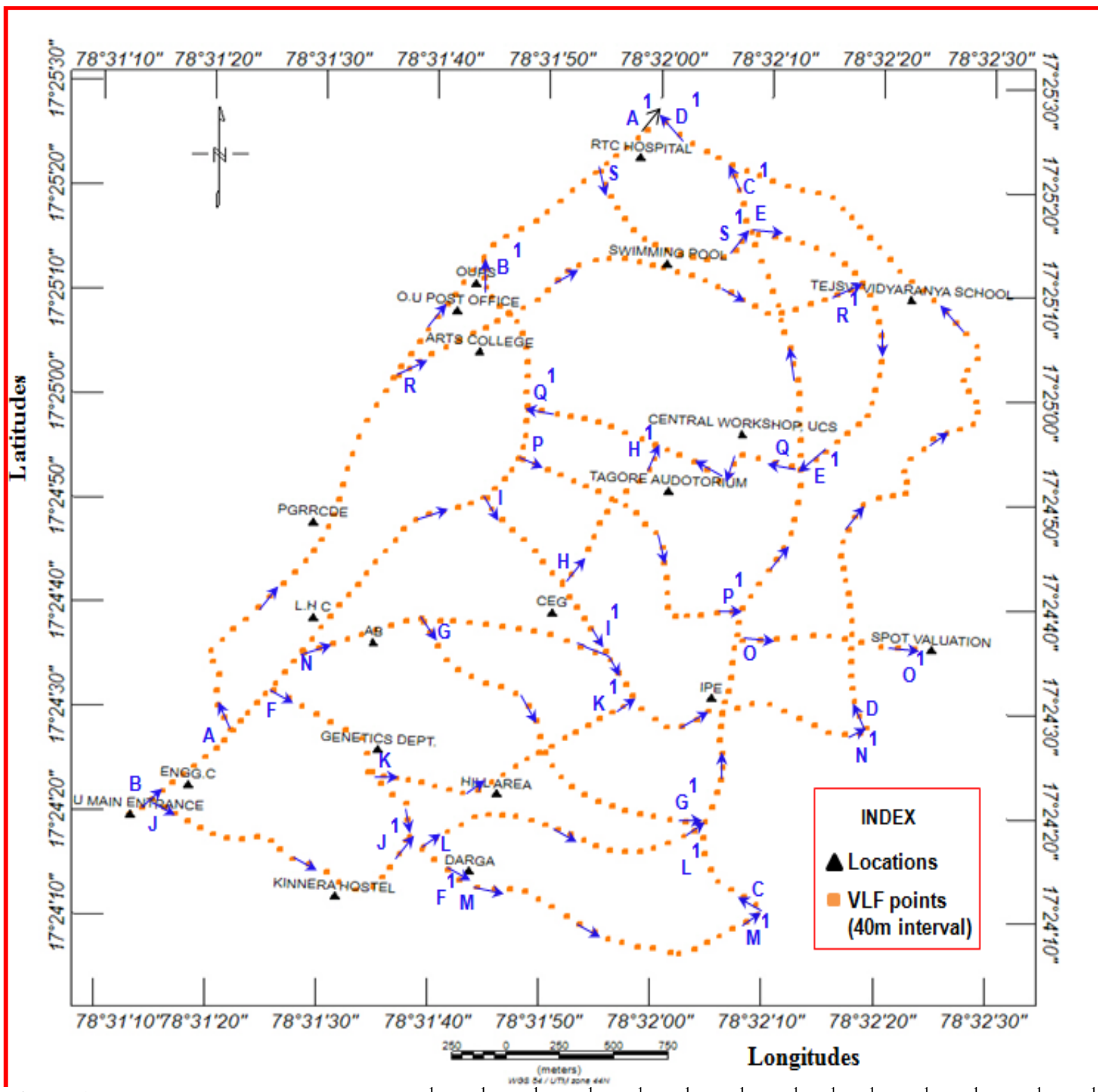

Figure 2:- Locations of VLF traverses $\left(\mathrm{AA}^{1}, \mathrm{BB}^{1}, \mathrm{CC}^{1}, \mathrm{DD}^{1}, \mathrm{EE}^{1}, \mathrm{FF}^{1}, \mathrm{GG}^{1}, \mathrm{HH}^{1}, \mathrm{II}^{1}, \mathrm{JJ}^{1}, \mathrm{KK}^{1}, \mathrm{LL}^{1}, \mathrm{MM}^{1}, \mathrm{NN}^{1}\right.$, $\mathrm{OO}^{1}, \mathrm{PP}^{1}, \mathrm{QQ}^{1}, \mathrm{RR}^{1}$ and $\mathrm{SS}^{1}$ )

\section{Analysis of VLF-EM data:-}

For quantitative interpretation, it is more useful to plot the real and imaginary data. The method of estimating depth to a linear conductor based on the peak to peak width of VLF vertical in-phase data. The depth is half the peak-topeak width, less the instrument's elevation above ground. This procedure was developed by Karous and Hjelt $\left(\mathrm{K} \& \mathrm{H}, 1983^{[12]}\right)$

The interpretation of VLF surveys in terms of buried conductors can be assisted by the application of the Karous and Hjelt, linear filter to the observed in-phase component of the vertical magnetic field. Karous and Hjelt filter technique are based on discrete linear filtering of VLF data. Starting with the Biot-Savart law to describe the magnetic field arising from a subsurface 2-D current distribution, these authors use linear filter theory to solve the integral equation for the current distribution, assumed to be located in a thin horizontal sheet of varying current density, situated everywhere at a depth equal to the distance between the measurement stations. By calculating the inverse filter at various depths (example $\Delta \mathrm{x}, 2 \Delta \mathrm{x}, 3 \Delta \mathrm{x}$ ), one can study the variation of current densities with depth. This filter is expressed as; 


$$
\frac{\Delta z}{2 \pi} I_{a}\left(\frac{\Delta x}{2}\right)=0.102 H_{-3}-0.059 H_{-2}+0.561 H_{-1}-0.561 H_{1}+0.059 H_{2}-0.102 H_{3} \ldots 1
$$

\section{Filtering of VLF-EM data:-}

\section{Karous \& Hjelt Filtering}

Where $\Delta \mathbf{z}$ is the assumed thickness of the current sheet, $\Delta \mathbf{x}$ is the distance between the data points and also the depth to the current sheet, location of the calculated current density is beneath the center point of the six data points. The values of $\mathrm{H}$ are the normalized vertical magnetic field anomaly at each of six data points. Details of the filter derivation can be found in Karous \& Hjelt $\left(1983^{[12]}\right)$.

Filtered VLF data help to locate vertical discontinuities such as hidden faults. K\&H filter technique also provides a useful complementary tool for the semi-quantitative analysis and target visualization from the surface to a few ten meters. The current density maxima seem always to occur within or around the conductors. As a result of this feature, current density pseudo sections can give diagnostic information for the target (Ogilvi and Lee, 1991 ${ }^{[13]}$ ).

\section{Fraser Filtering:-}

A simple filtering technique that transforms crossovers into peaks, removes regional gradients and also amplifies anomalies from near surface was suggested by Fraser, $1969^{[14]}$. The filter (Fraser) is applied to the in-phase (real), Quadrature (imaginary) component data and presented in the form of a contour map (Figure: $3 \& 4$ ). The negative contours are due to the false crossovers and are discarded. Based on the contour pattern it may be inferred that the conductive are probably a result of en-echelon-type complex fracture systems.

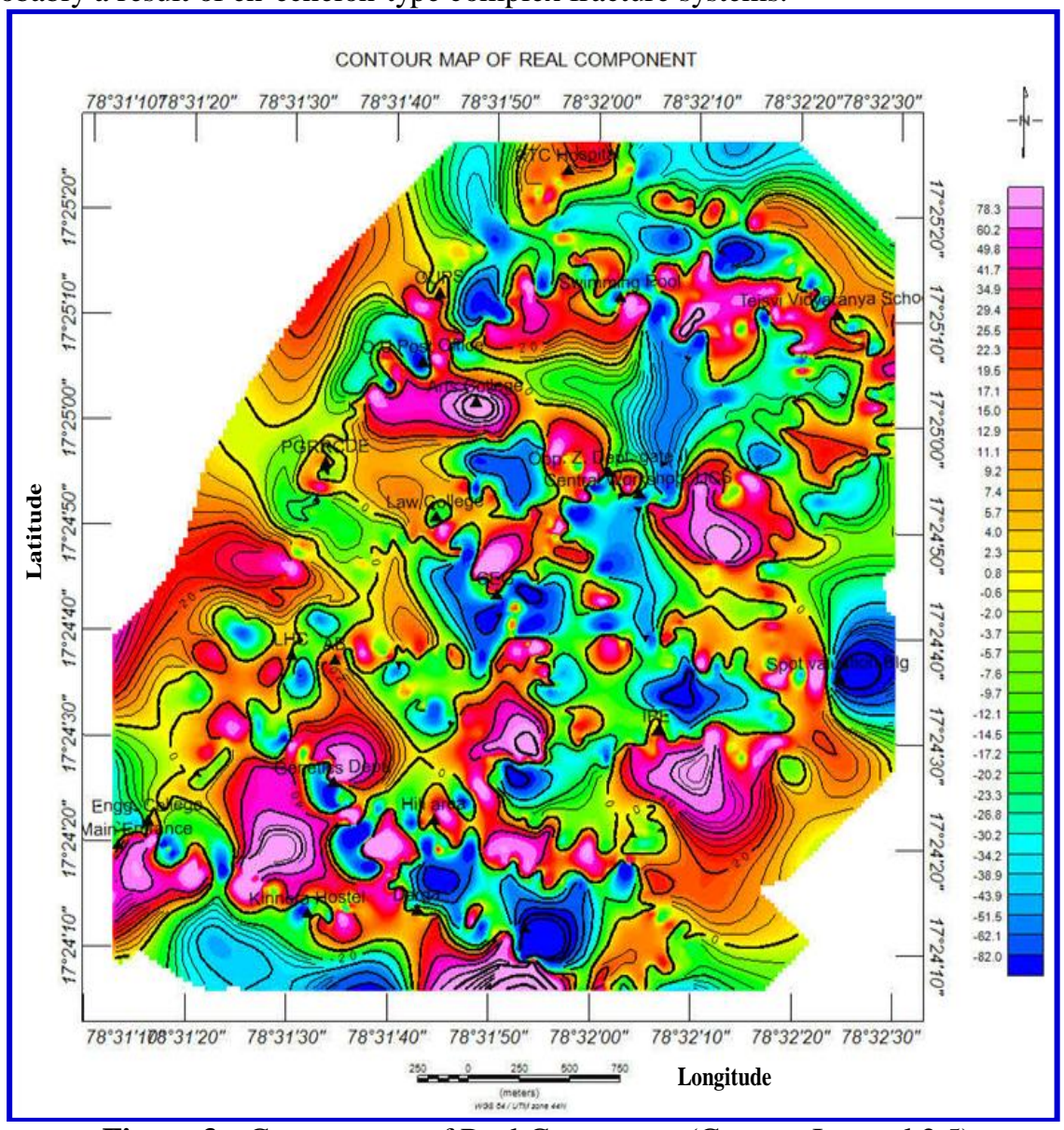

Figure 3:- Contour map of Real Component (Contour Interval 2.5) 


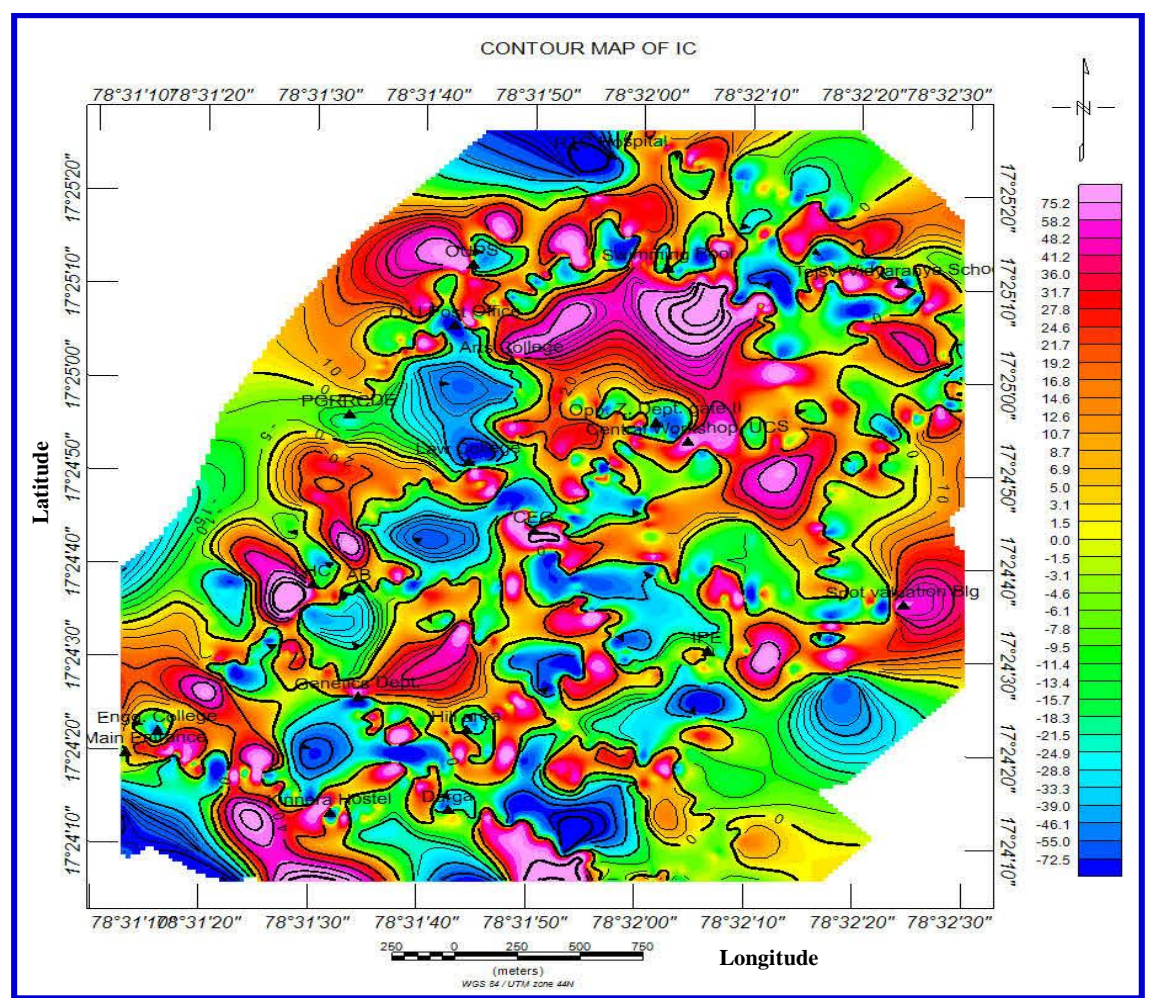

Figure 4:- Contour map of Imaginary Component (Contour Interval 2.5)

\section{Fraser filtered pseudo-sections:-}

An additional interpretation tool is pseudo-section obtained through filtering (Wright, $1988^{[15]}$ ). Such a section is produced by processing a given data profile with filters of various lengths. As the length of the filter increases, response from increasing depth is successively emphasized. Pseudo-sections are prepared for traverses $\mathrm{AA}^{1}$ to $\mathrm{SS}^{1}$ with two filters by normalizing each time with its filter lengths of the filtered in-phase component.

\section{Interpretation of VLF-EM traverses:-}

Electromagnetic VLF traverses ( $\mathrm{AA}^{1}$ to $\mathrm{SS}^{1}$ ) are carried all along parallel to the roads (10m away from the roads) in the N-S \& E-W direction. Nineteen traverses in all were taken up. Plots of the filtered real and imaginary parts were produced for every traverse and they were interpreted in view of the existence of conductive zones that could be related to tectonic faults.

Traverse- $\mathbf{A A}^{\mathbf{1}}$ is running in the N-S direction about $2000 \mathrm{~m}$ long towards west of the study area and it traverse from UFRO - under the Adikmet flyover - PGRRCDE - EFLU -Bed College to Tarnaka Junction.

Fraser filtering (Fraser, $1969^{[14]}$ ) responses ranged in value from $-100 \%$ to $98 \%$ along the traverse. Figure: 5 (a) shows the Fraser filtered data (real or in-phase component and imaginary or quadrature component). The in-phase traverses show positive peaks of different values of relative current density correspond to higher values of resistivity. All the VLF-EM intensities and sharpness were suggesting the presence of shallow and deep conductors. Lower traverses in this study were processed using the Karous-Hjelt filter (Karous and Hjelt, $1983^{[12]}$ ). Conductors (colored red) were delineated from equivalent current density pseudo sections along traverse $\mathrm{AA}^{1}$. A higher value of relative current density is regarded as conductive subsurface structures, such as fractures, which often store groundwater in hardrock terrains. The 2-D inversion shows the variation of equivalent current density, and change in conductivity with depth. With such equivalent current density cross-section plots, it is possible to qualitatively discriminate between conductive and resistive structures where a high positive value corresponds to the conductive subsurface structure and low negative values are related to resistive materials. In addition, equivalent current density cross-section also gives an idea about the dip direction; however, exact dip angle cannot be estimated due to the vertical axis variable being a pseudo depth only. 
The equivalence current density pseudo section of traverse (Figure: $5 \mathrm{~b}$ ) reveals the presence of major anomalies at the southern side between $590 \mathrm{~m}$ and $710 \mathrm{~m}$, and at the northern side between $1400 \mathrm{~m}$ and $1490 \mathrm{~m}$ with depth of 20 to $60 \mathrm{~m}$, which can be referred to as fracture zone. Furthermore, two high current density zones between $300 \mathrm{~m}$ and $350 \mathrm{~m}$, and $510 \mathrm{~m}$ along the traverse can also be referred to as indications of the potential subsurface fracture system (Figure: 5 b). Asymmetry in the observed real and imaginary anomalies suggests the dipping nature of a subsurface conductive body. The Fraser filtering data plots and the Karous-Hjelt current density plot for traverse as presented in Figure: 5 (a) reveals a number of anomalies, which reflects conductive subsurface structural trends of inferred fractures zones (at 500, 640 and 1450m) along the traverse.

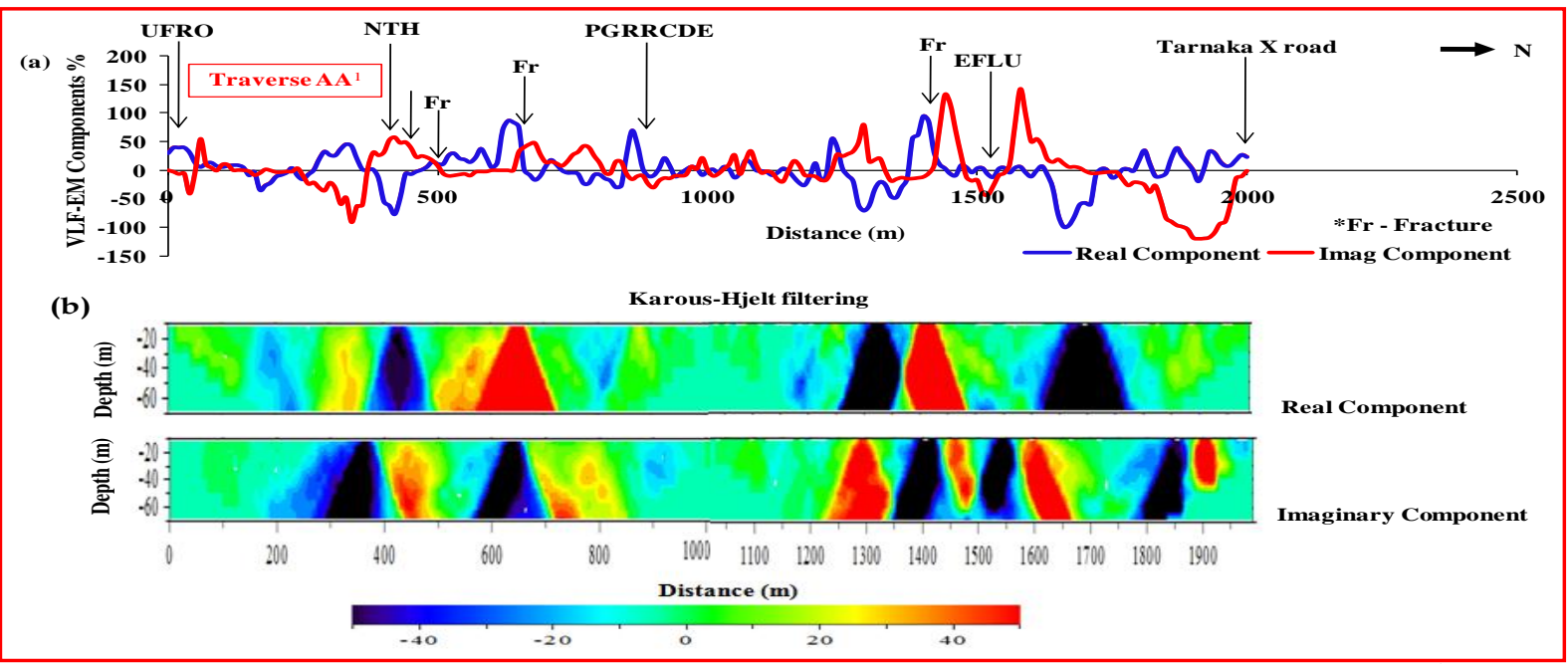

Figure: 5 (a), (b):- Fraser filtering graph and equivalent current density pseudo-section of Traverse $\mathrm{AA}^{1}$.

Traverse-BB ${ }^{1}$ is running $2200 \mathrm{~m}$ and trending in N-S direction, lies towards west of the study area and it traverse from O.U Main Entrance - Engineering College - Ladies Hostel - Law College - Arts College to O.U Police Station.

Figure: 6(a) shows the Fraser filtered data of in-phase and quadrature component, responses ranged in value from $100 \%$ to $175 \%$ along the traverse.

Figure: 6 (b) shows the corresponding K-H pseudo section of traverse $\mathrm{BB}^{1}$. The pseudo section is a measure of the conductivity of the subsurface as a function of depth. The conductivity shown as color codes with conductivity increasing from left to right (i.e., from negative to positive). Different features of varying degree of conductivity trending in different directions are delineated on the section, for instance, between stations $515 \mathrm{~m}$ and $620 \mathrm{~m}$ and between stations $1745 \mathrm{~m}$ and $1830 \mathrm{~m}$, highly and major conductive bodies respectively at approximate depth of $70 \mathrm{~m}$ are indicated. Figure: 6(a) reveals a number of anomalies, which reflects conductive subsurface structural trends of inferred fractures zones (at 490 and $1850 \mathrm{~m}$ ) along the traverse. 


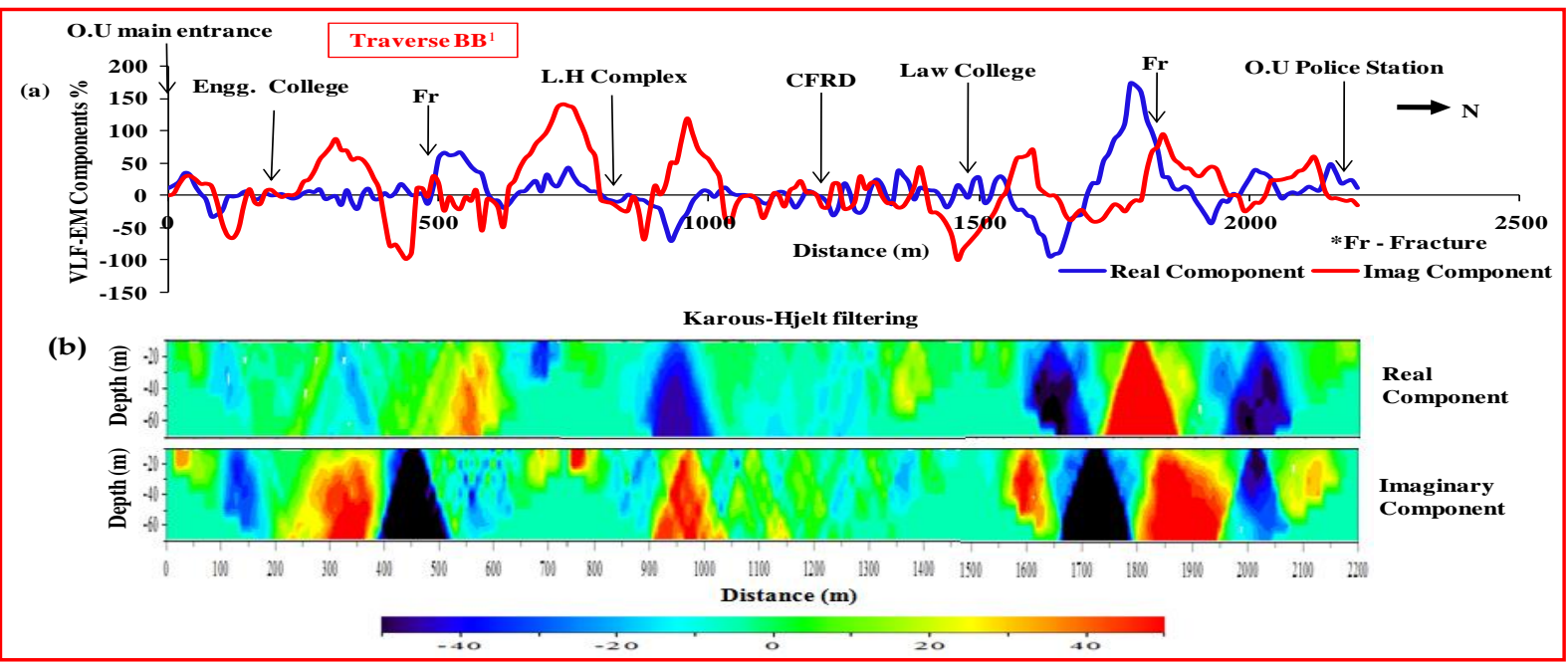

Figure: 6 (a), (b):- Fraser filtering graph and equivalent current density pseudo-section of Traverse $\mathrm{BB}^{1}$.

Traverse-CC ${ }^{1}$ is situated east of the O.U Campus, about $2400 \mathrm{~m}$ long and it runs from a point towards IPE, in N-S direction nearby Darga which is behind the Genetics Dept. - IPE - behind the residences of Maneru Hostel Professors Quarters - Indore Stadium to Aradana Theater.

Figure: 7(a) shows the percentage of real and imaginary component of Fraser filtered data with ground distances, ranged in values from $-120 \%$ to $153 \%$ along the traverse.

Figure: 7(b) shows a highly conductive body between stations $1400 \mathrm{~m}$ and $1510 \mathrm{~m}$ and major conductive body is indicated between stations $2035 \mathrm{~m}$ and $2170 \mathrm{~m}$ at an approximate depth of $70 \mathrm{~m}$ and also a low conductive body between $1550 \mathrm{~m}$ and $1575 \mathrm{~m}$ with approximate depth of $30 \mathrm{~m}$. Figure: 7(a) reveals a number of anomalies, which reflects conductive subsurface structural trends of inferred fractures zones (at 1470 and 2070m) along the traverse.

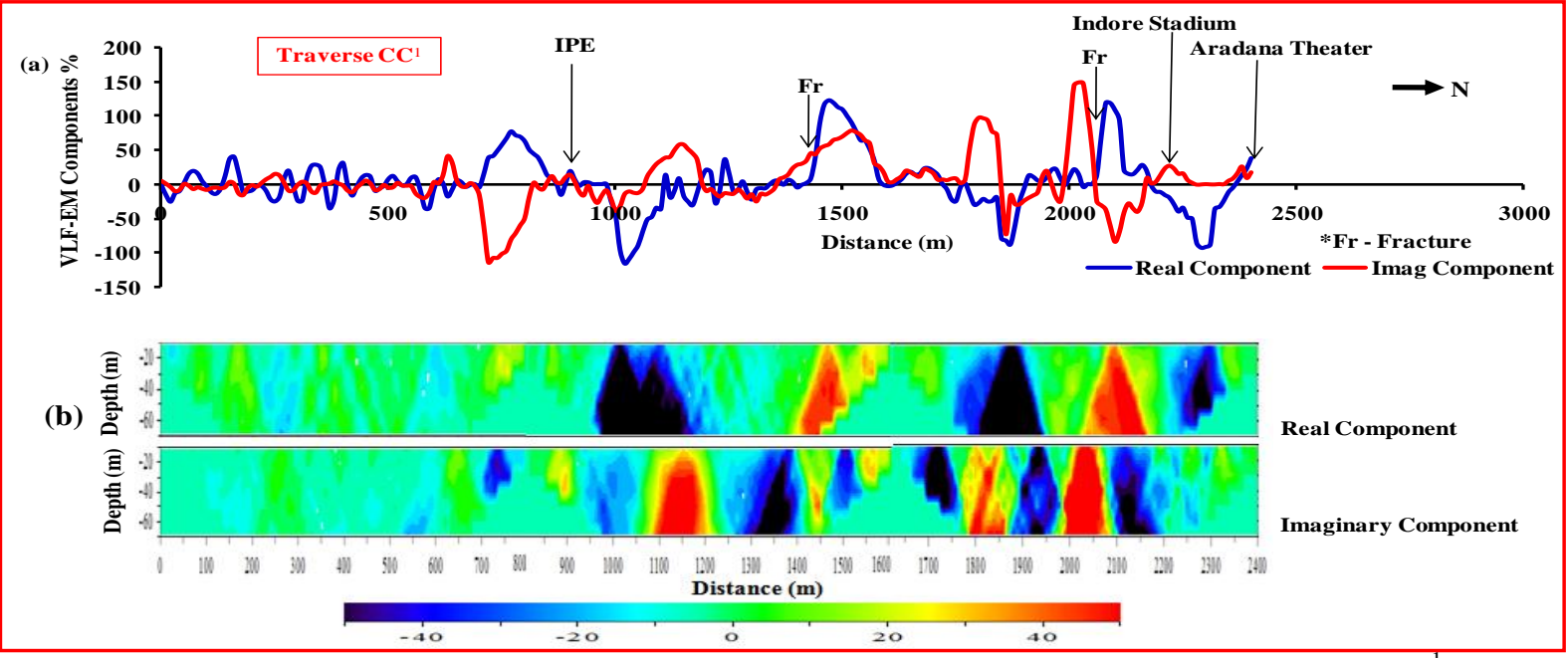

Figure: 7 (a), (b):- Fraser filtering graph and equivalent current density pseudo-section of Traverse $\mathrm{CC}^{1}$.

Traverse-DD ${ }^{1}$ is running from a way out to Ramanthapur near IPE residences via a junction road near Spotvaluation, Residences, Burial Ground, Habsiguda Harithavanam, Tejasvi Vidyaranya School, Behind the Swagath Grand Hotel, Huda Complex, and 'A' Ground to Taranaka Junction with a total length of 2430m and is situated east of the study area.

Figure: 8 (a) shows the values ranged from $-100 \%$ to $175 \%$ is the real and imaginary component response of Fraser filtered data. 
Figure: 8(b) shows different features of varying degree of conductivity, for instance, between stations $1920 \mathrm{~m}$ and $2045 \mathrm{~m}$ and between stations $2085 \mathrm{~m}$ and $2190 \mathrm{~m}$, major conductive bodies at an approximate depth of $70 \mathrm{~m}$ are indicated. The section shows several closures of conductive bodies at different depths. Figure: 8(a) reveals a number of anomalies, which reflects conductive subsurface structural trends of inferred fractures zones (at 1350, 1950 and $2200 \mathrm{~m}$ ) along the traverse.

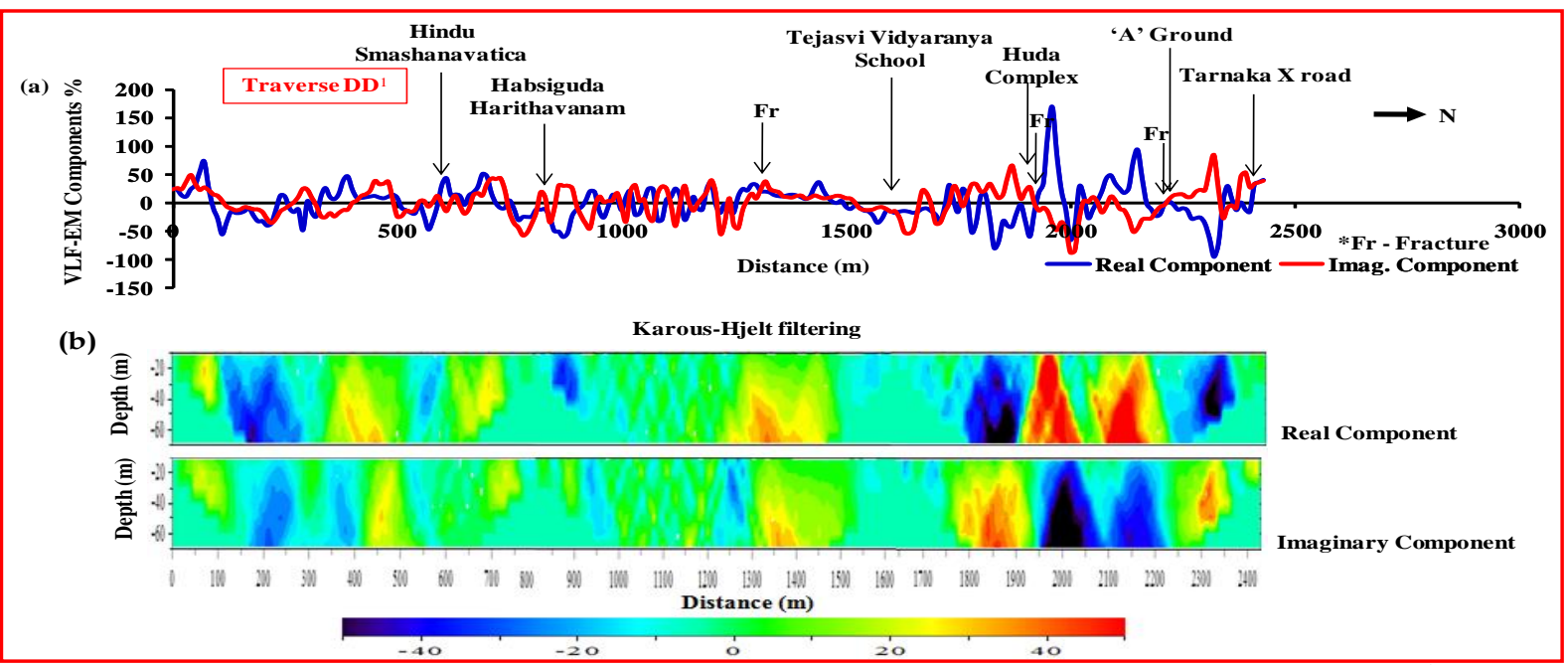

Figure: 8(a), (b):- Fraser filtering graph and equivalent current density pseudo-section of Traverse $\mathrm{DD}^{1}$.

Traverse-EE ${ }^{1}$ indicates the path in N-S directions and it starts from Indoor Stadium Entrance - Professors Quarters - to its Junction road before Central Workshop, UCS with total length of 920m and lies towards north of the study area.

Figure: 9(a) shows the real and imaginary component response range from $-160 \%$ to $195 \%$ of Fraser filtered data.

Figure: 9(b) shows a major conductive body at an approximate depth of $70 \mathrm{~m}$ between stations $220 \mathrm{~m}$ and $440 \mathrm{~m}$, forming an M-shaped conductive body. Also, a highly conductive body between stations $50 \mathrm{~m}$ and $80 \mathrm{~m}$ at an approximate depth of 30m, existing north side of the section. Figure: 9(a) reveals a number of anomalies, which reflects conductive subsurface structural trends of inferred fractures zones (at 70, 300 and 370m) along the traverse.

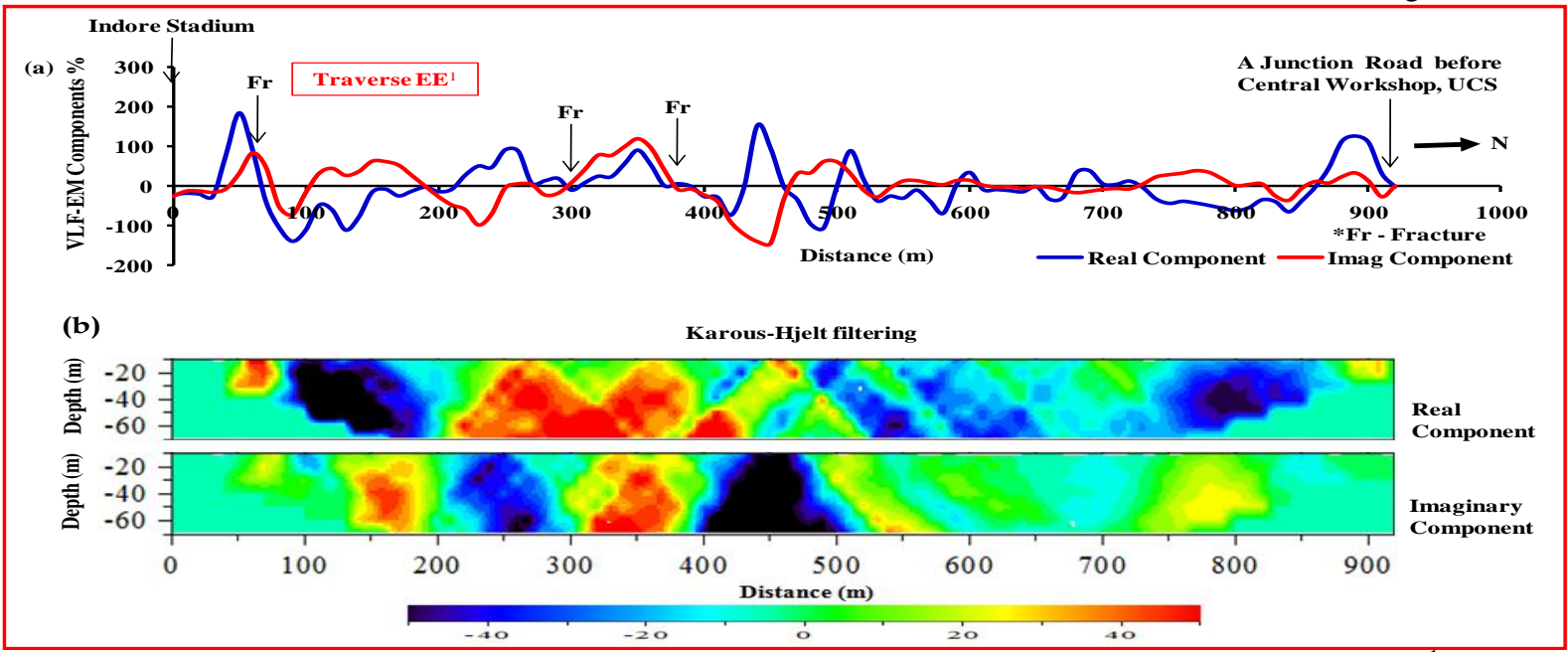

Figure: 9 (a), (b):- Fraser filtering graph and equivalent current density pseudo-section of Traverse $\mathrm{EE}^{1}$.

Traverse-FF ${ }^{1}$ has the path in E-W directions and it starts from Ganga Hostel - Genetics and Microbiology Departments to Darga with total length of $720 \mathrm{~m}$ and lies towards south of the study area. 
Figure: 10(a) shows the response of real and imaginary Fraser filtered data ranged from $-400 \%$ to $390 \%$.

Figure: 10(b) shows different features of varying degree of conductivity trending in different directions, for instance, between stations $460 \mathrm{~m}$ and 550m, major conductive body at an approximate depth of 70m trending in NW-SE. Highly conductive body between stations $360 \mathrm{~m}$ and $415 \mathrm{~m}$ is indicated. There are several pockets of highly conductive bodies cross-cut between stations $135 \mathrm{~m}$ and $285 \mathrm{~m}$ forming V-shaped conductive body. Generally, the section shows several closures of conductive bodies at different depths. Figure: 10(a) reveals a number of anomalies, which reflects conductive subsurface structural trends of inferred fractures zones (at 270, 390 and 500m) along the traverse.

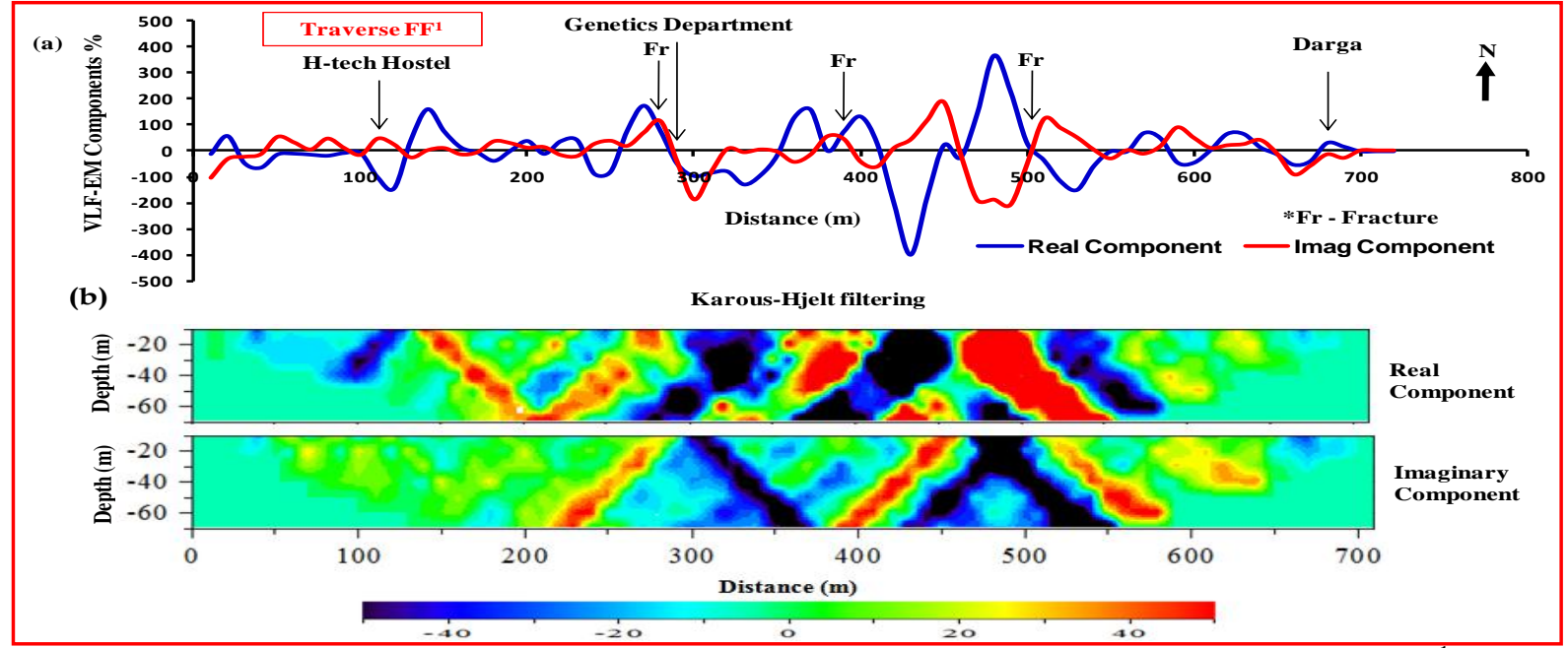

Figure: 10 (a), (b):- Fraser filtering graph and equivalent current density pseudo-section of Traverse $\mathrm{FF}^{1}$.

Traverse-GG ${ }^{1}$ starts from Cafeteria - V.C Lodge-through Forest -to a road towards to IPE with the total length of $960 \mathrm{~m}$ and lies towards south of the O.U Campus.

Figure: 11(a) reveals the anomaly response of real and imaginary Fraser filtered data ranged from $-80 \%$ to $125 \%$.

Figure: 11(b) is a section of the conductive body with linear major conductive bodies are very closely adjacent to each other as overlapping at an approximate depth of $70 \mathrm{~m}$ between stations $34 \mathrm{~m}$ and $500 \mathrm{~m}$. Towards the eastern part of the section, a highly conductive body is indicated between stations $795 \mathrm{~m}$ and $860 \mathrm{~m}$ at an approximate depth of $65 \mathrm{~m}$. Figure: 11(a) reveals a number of anomalies, which reflects conductive subsurface structural trends of inferred fractures zones (at 300, 440 and 720m) along the traverse. 


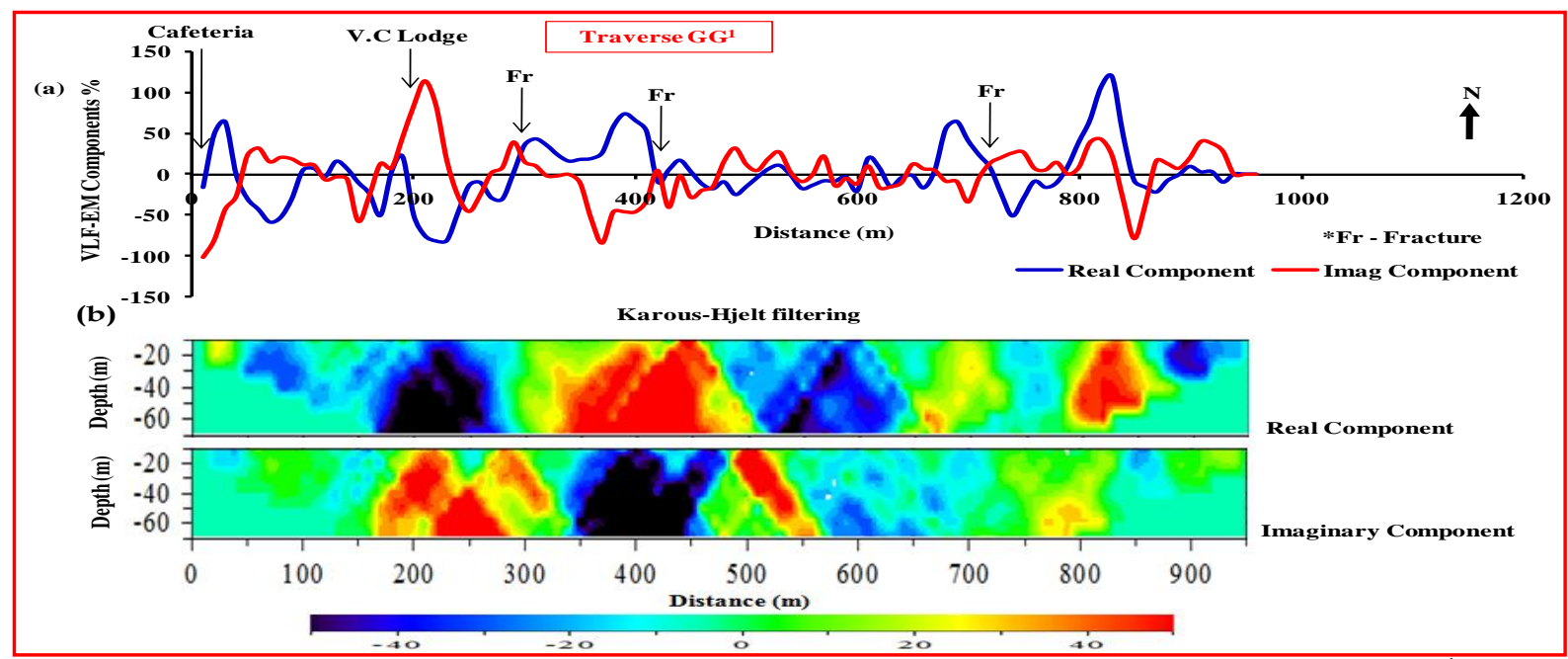

Figure: 11(a), (b):- Fraser filtering graph and equivalent current density pseudo-section of Traverse $\mathrm{GG}^{1}$.

Traverse $\mathbf{H H}^{1}$-is in N-S direction and lies middle of the study area with the total length of $490 \mathrm{~m}$, it starts from a road junction adjacent to Geography - Tagore Auditorium road - to Botanical Garden $2^{\text {nd }}$ Gate, which is opposite to Botany and Zoology Department.

Figure: 12(a) shows the percentage of anomaly response of real and imaginary Fraser filtered data ranged from $280 \%$ to $390 \%$.

Figure: 12(b) is conductive body section with a linear major conductive body in the vertical direction between stations $215 \mathrm{~m}$ and $340 \mathrm{~m}$ at an approximate depth of $70 \mathrm{~m}$. Figure: 12 (a) reveals a number of anomalies, which reflects conductive subsurface structural trends of inferred fractures zones (at $260 \mathrm{~m}$ ) along the traverse.

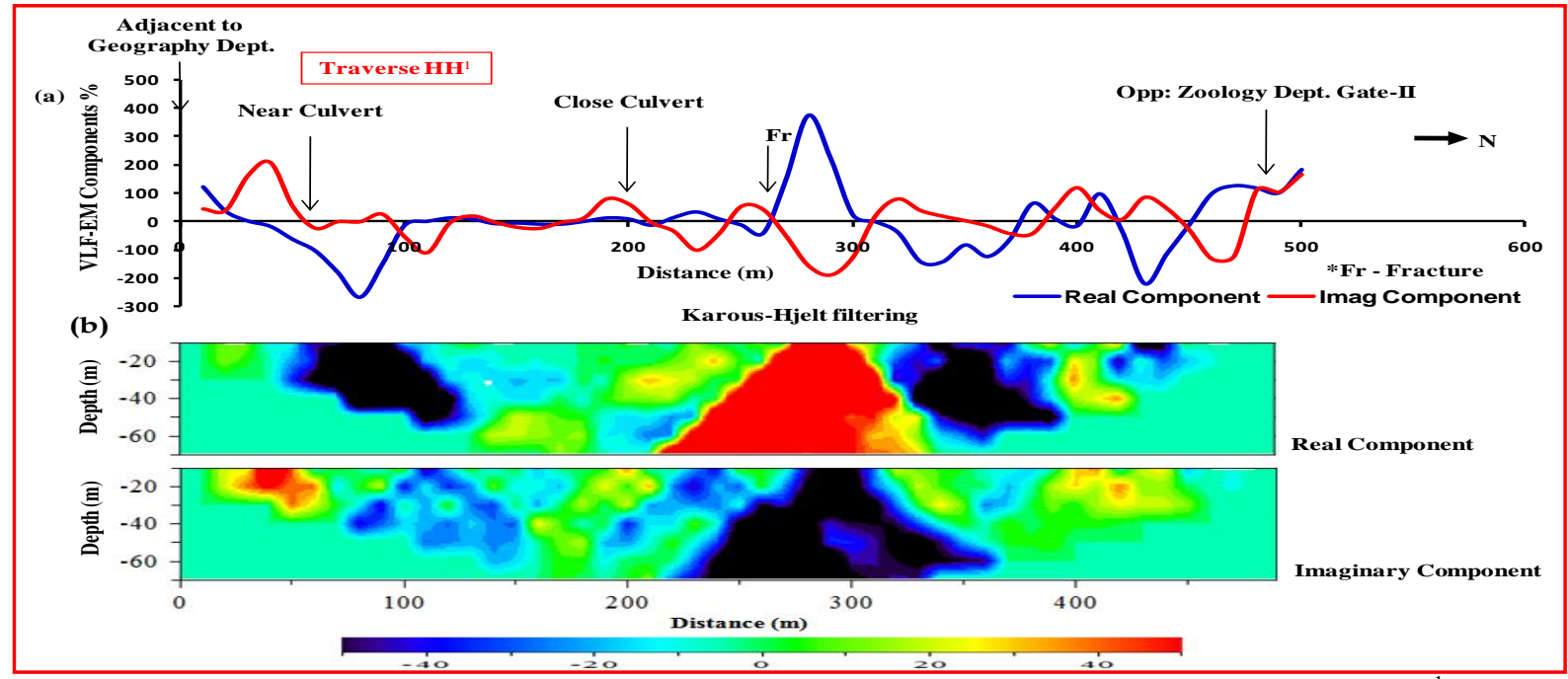

Figure: 12a), (b):- Fraser filtering graph and equivalent current density pseudo-section of Traverse $\mathrm{HH}^{1}$.

Traverse- $\mathbf{I I}^{\mathbf{1}}$ runs from opposite to Law College (Adjacent to Landscape Garden)-' D' Hostel-Geophysics Department to a junction road towards O.U Press, in E-W trending with a total length of $560 \mathrm{~m}$ and lies middle of the study area.

Figure: 13(a) shows the anomaly response of real and imaginary Fraser filtered data, the percentage ranged from $190 \%$ to $250 \%$. 
In figure: 13(b) different features of varying degree of conductivity are delineated on the section, for instance, between stations $150 \mathrm{~m}$ and $220 \mathrm{~m}$, and $410 \mathrm{~m}$ and $490 \mathrm{~m}$ major conductive bodies are shown. Similarly, between stations $220 \mathrm{~m}$ and $245 \mathrm{~m}$, and $520 \mathrm{~m}$ and $560 \mathrm{~m}$, highly conductive bodies at an approximate depth of $50 \mathrm{~m}$ and $25 \mathrm{~m}$ respectively present on the section. Figure: 13(a) reveals a number of anomalies, which reflects conductive subsurface structural trends of inferred fractures zones (at170, 230, 410, 450 and 530m) along the traverse.

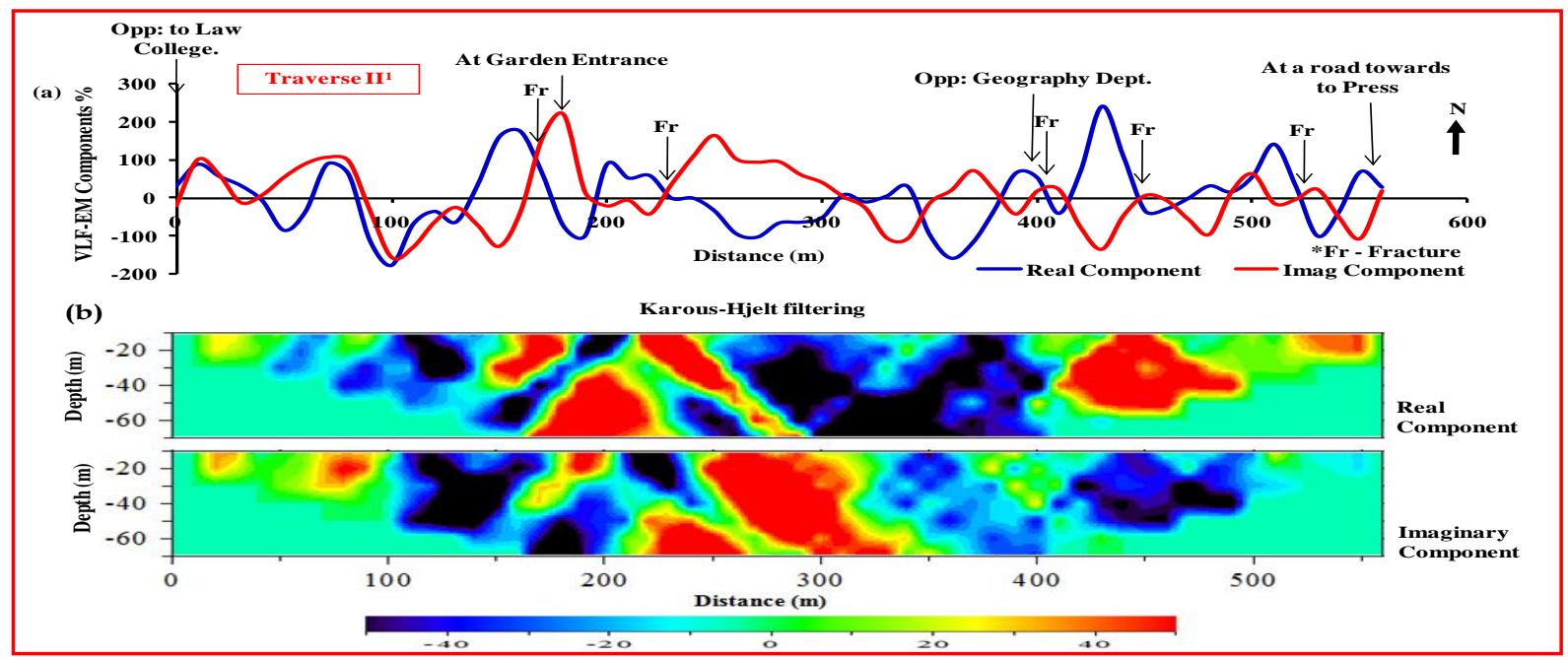

Figure: 13 (a), (b):- Fraser filtering graph and equivalent current density pseudo-section of Traverse II $^{1}$.

Traverse- $\mathbf{J} \mathbf{J}^{\mathbf{1}}$ is $760 \mathrm{~m}$ long in E-W trending lies south of the study area and it traverse from a road opposite to Telangana Mahila Sabha - Kinnera Hostel - to behind the Genetics Department - and close to Darga.

Figure: 14(a) shows real and imaginary Fraser filtered data response, the percentage ranged from $-200 \%$ to $220 \%$.

Figure: 14(b). The section is a conductive body with the highly conductive body between stations $50 \mathrm{~m}$ and $80 \mathrm{~m}$ at an approximate depth of $32 \mathrm{~m}$. Also, between stations $180 \mathrm{~m}$ and $205 \mathrm{~m}$ at an approximate depth of $70 \mathrm{~m}$ in the vertical direction is shown. Several other closures of conductive bodies are present on the section with each conductive body coinciding with the points already identified on the profile as the fracture. Figure: 14 (a) reveals a number of anomalies, which reflects conductive subsurface structural trends of inferred fractures zones (at 60, 190, 350 , and $440 \mathrm{~m}$ ) along the traverse.

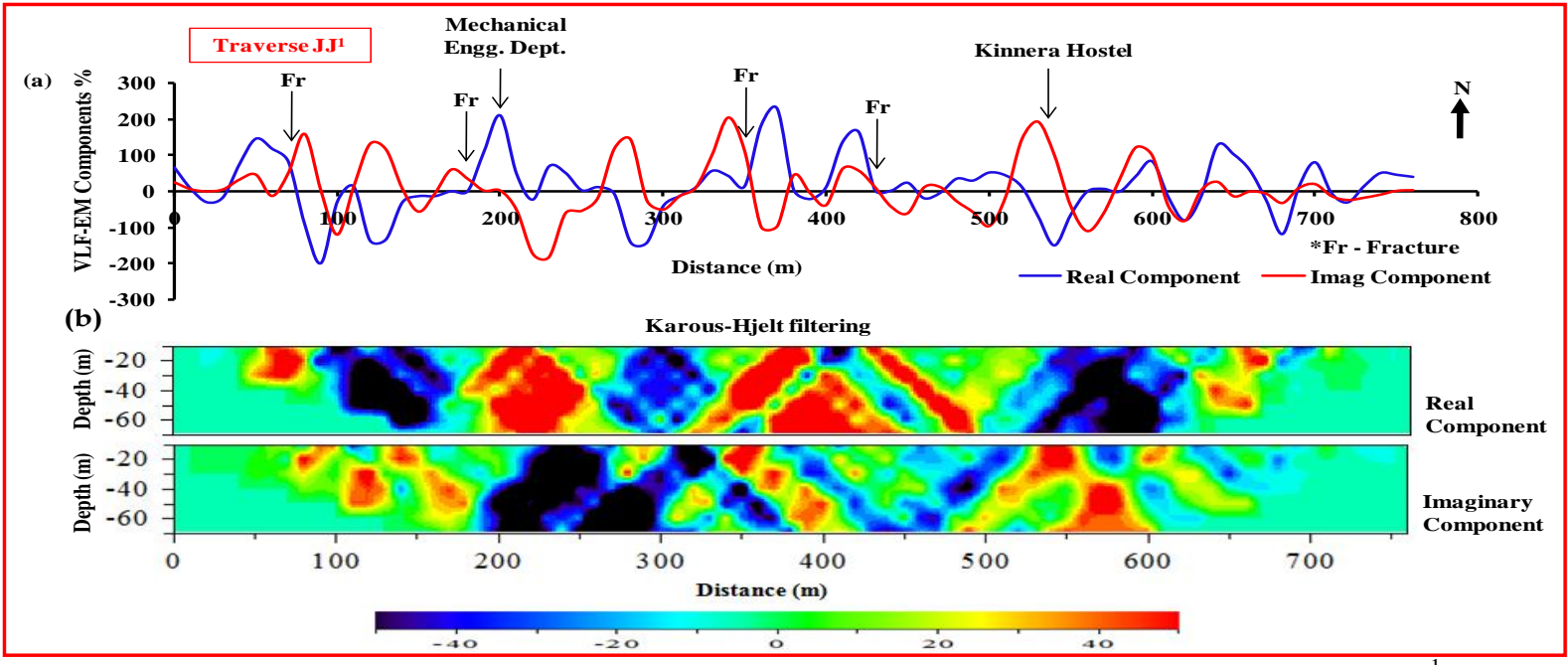

Figure: 14 (a), (b):- Fraser filtering graph and equivalent current density pseudo-section of Traverse $\mathrm{JJ}^{1}$. 
Traverse-KK ${ }^{\mathbf{1}}$ is in E-W direction, passing from behind the Genetics Department, close to open Well - Hill Area through Forest - to Sports Hostel front side Boundary wall with a total length of $730 \mathrm{~m}$ and situated towards south of the study area.

Figure: 15(a) shows positive and negative peaks of the real and imaginary Fraser filter data, ranged from -190\% to $240 \%$.

Figure: 15(b) shows major conductive bodies between stations $300 \mathrm{~m}$ and $400 \mathrm{~m}$, and $465 \mathrm{~m}$ and $550 \mathrm{~m}$ at an approximate depth of $70 \mathrm{~m}$. Eastern part of the section shows a highly conductive body between stations $690 \mathrm{~m}$ and $740 \mathrm{~m}$ at an approximate depth of $22 \mathrm{~m}$. Figure: 15(a) reveals a number of anomalies, which reflects conductive subsurface structural trends of inferred fractures zones (at 300,500 and 710m) along the traverse.

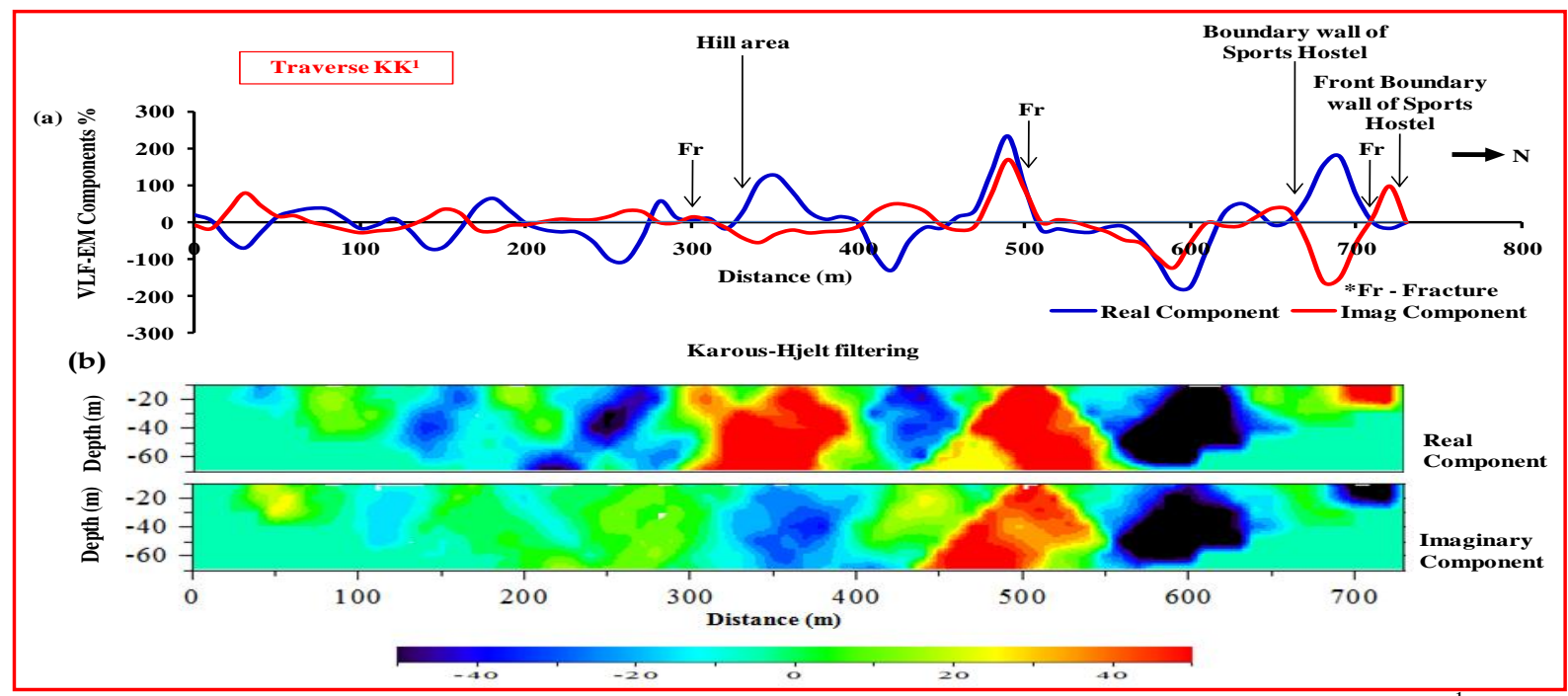

Figure: 15 (a), (b):- Fraser filtering graph and equivalent current density pseudo-section of Traverse $\mathrm{KK}^{1}$.

Traverse- $\mathbf{L} \mathbf{L}^{\mathbf{1}}$ indicates the path in E-W direction all along the $790 \mathrm{~m}$ length to south of the study area and it starts from Darga (Behind the Genetics Department) - through Forest - to Towards IPE road.

Figure: 16 (a) shows Fraser filter data, the percentage of positive and negative peaks of the real and imaginary components, ranged from $-200 \%$ to $120 \%$.

Figure: 16 (b) shows several closures and pockets of features of conductive bodies at varying degree of conductivity. Between stations $340 \mathrm{~m}$ and $550 \mathrm{~m}$, a major conductive body at an approximate depth of $70 \mathrm{~m}$ is indicated. Figure: 16(a) reveals a number of anomalies, which reflects conductive subsurface structural trends of inferred fractures zones (at 410 and $490 \mathrm{~m}$ ) along the traverse. 


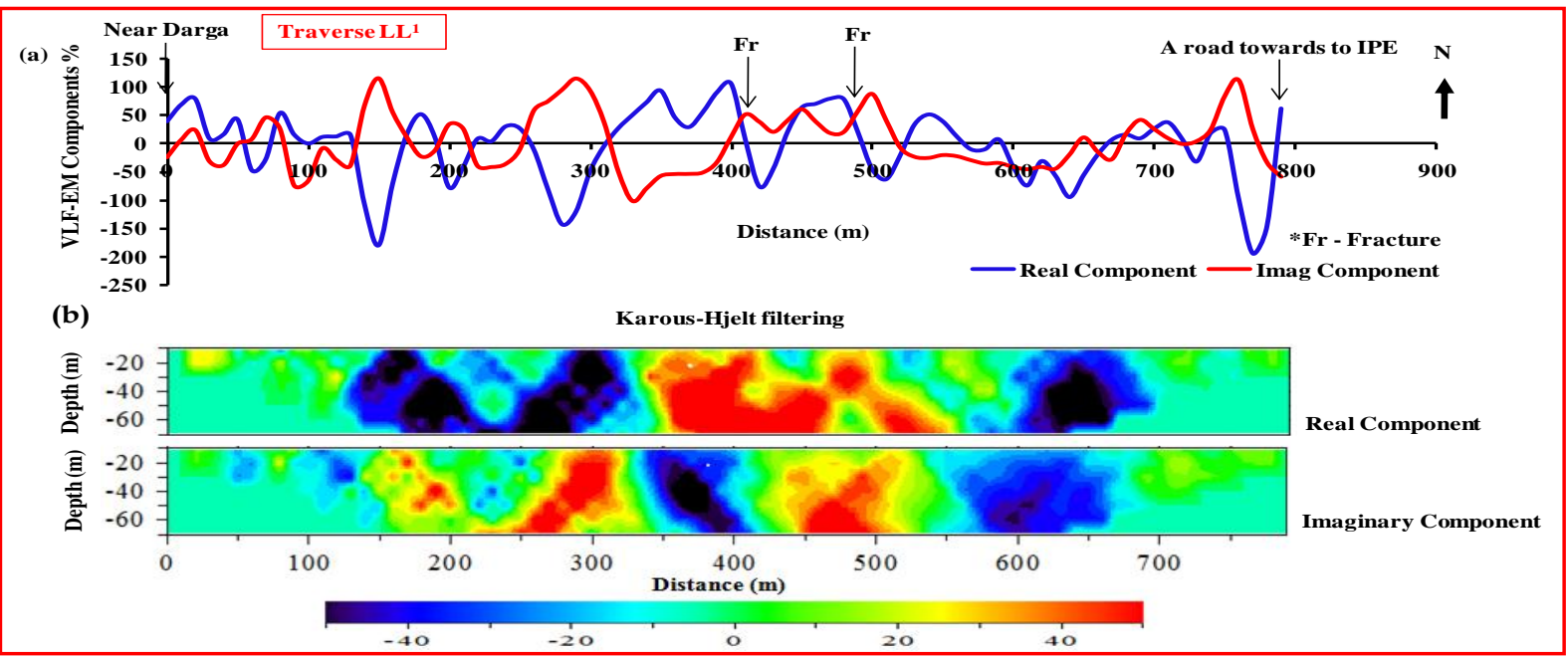

Figure: 16 (a), (b):- Fraser filtering graph and equivalent current density pseudo-section of Traverse $\mathrm{LL}^{1}$.

Traverse- $-\mathrm{MM}^{1}$ indicates its traverse in E-W direction all along the $560 \mathrm{~m}$ length to south of the study area and it starts from ending station of $\mathrm{FF}^{1}$ traverse near Darga (Behind the Genetics Department) inside the Forest - to a road up to a N-S direction.

Figure: 17 (a) shows the Fraser filtered data of in-phase and quadrature component, responses ranged in value from $-100 \%$ to $175 \%$ along the traverse.

Figure: $17(\mathrm{~b})$ is a section of the highly conductive body between stations $220 \mathrm{~m}$ and $240 \mathrm{~m}$ at an approximate depth of $2 \mathrm{~m}$. Figure: 17 (a) reveals a number of anomalies, which reflects conductive subsurface structural trends of inferred fractures zones (at 240 and $250 \mathrm{~m}$ ) along the traverse.

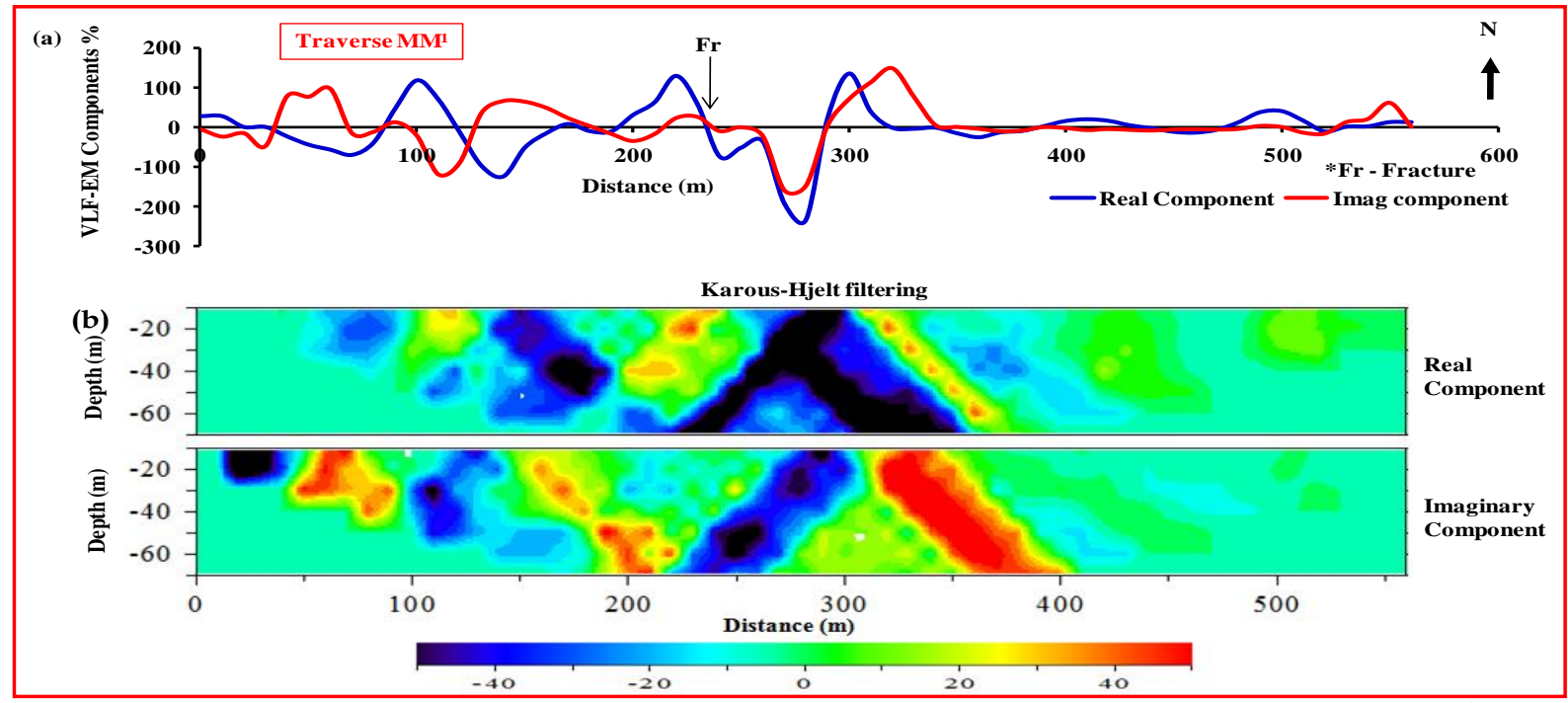

Figure: 17 (a), (b):- Fraser filtering graph and equivalent current density pseudo-section of Traverse $\mathrm{MM}^{1}$.

Traverse- $-\mathbf{N N}^{1}$ this $1560 \mathrm{~m}$ and trending in an E-W direction lays towards below middle part of the study area and it traverse from Renuka Yellamma Temple - Administrative Building - College of Technology - IPE - to Dead End of the Residences Area.

Figure: 18 (a) shows the Fraser filtered data of in-phase and quadrature component, responses ranged in value from $-140 \%$ to $150 \%$ along the traverse. 
Figure: 18 (b) revealed occurrence of major conductive bodies between stations $640 \mathrm{~m}$ and $715 \mathrm{~m}$, and 900m and $990 \mathrm{~m}$ at an approximate depth of $52 \mathrm{~m}$ and $60 \mathrm{~m}$ respectively. There are several pockets of highly conductive bodies are indicted along section at different depths. Figure: 18(a) reveals a number of anomalies, which reflects conductive subsurface structural trends of inferred fractures zones (at 700 and 1200m) along the traverse.

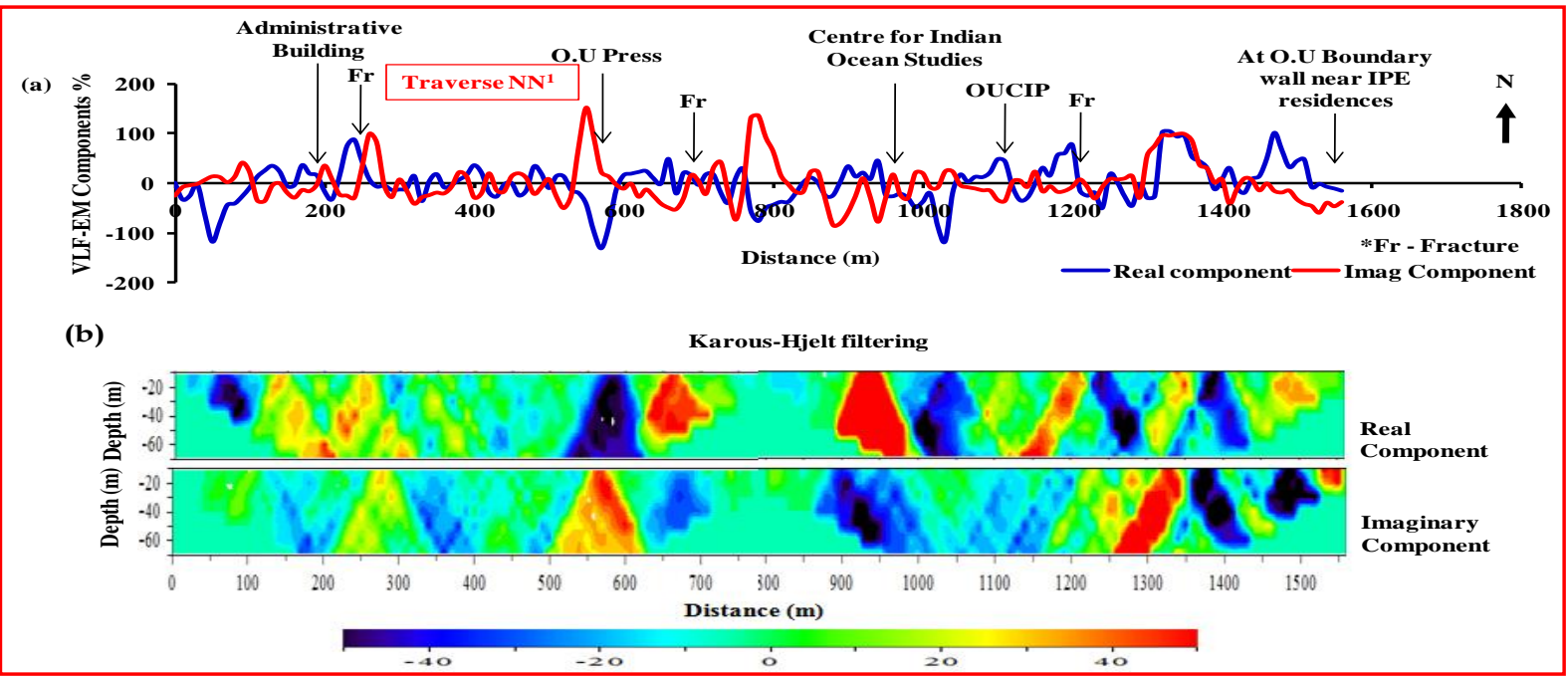

Figure: 18(a), (b):- Fraser filtering graph and equivalent current density pseudo-section of Traverse $\mathrm{NN}^{1}$.

Traverse--OOO ${ }^{1}$ starts from O.U Darga (Near Maneru Hostel) - to Spot Valuation Building running a total length of $440 \mathrm{~m}$ to the east of study area.

Figure: 19(a) shows the in-phase and quadrature component percentage responses of Fraser filtered data, ranged in value from $-140 \%$ to $150 \%$ along the traverse.

Figure: 19 (b) shows a major conductive body at an approximate depth $45 \mathrm{~m}$ between stations $340 \mathrm{~m}$ and $405 \mathrm{~m}$. Similarly, between stations $220 \mathrm{~m}$ and $305 \mathrm{~m}$, a linear highly conductive body is indicated. Figure: 19 (a) reveals a number of anomalies, which reflects conductive subsurface structural trends of inferred fractures zones (at 70 and $330 \mathrm{~m}$ ) along the traverse.

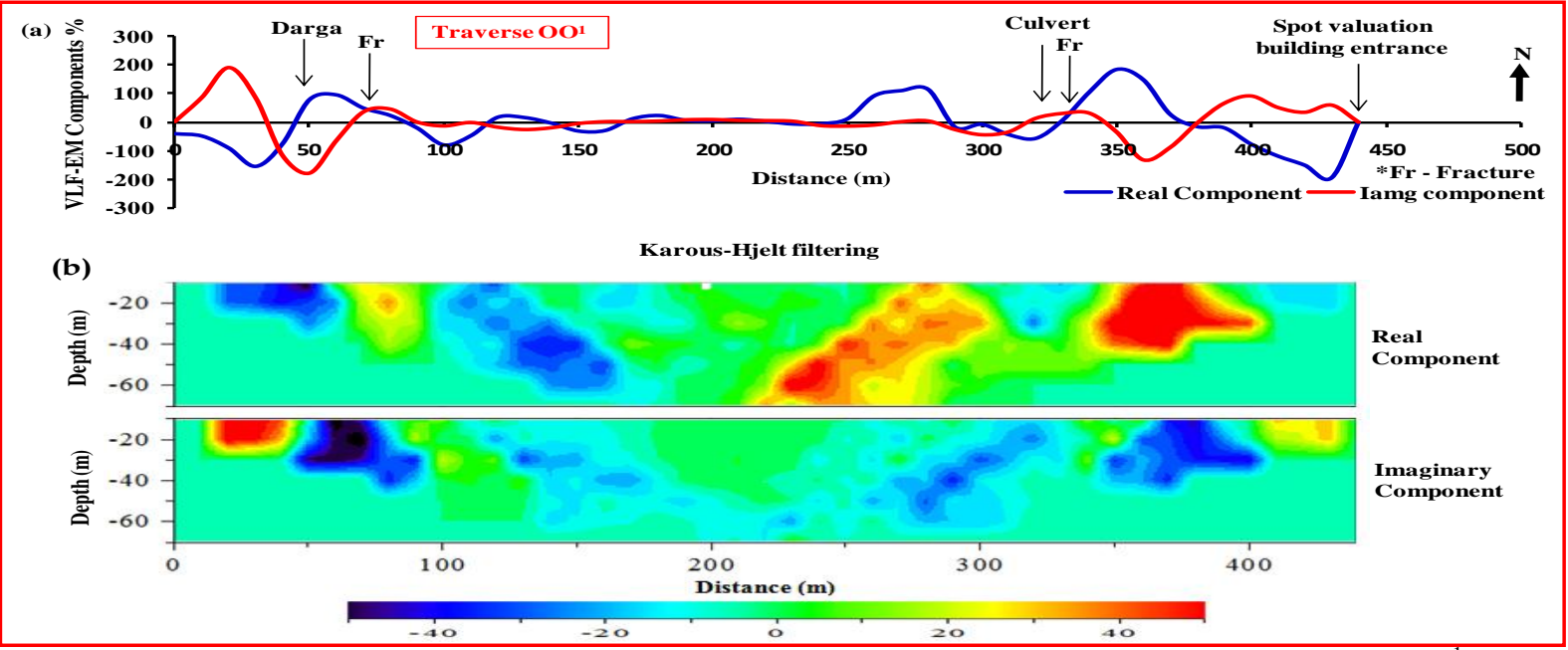

Figure: 19 (a), (b):- Fraser filtering graph and equivalent current density pseudo-section of Traverse $\mathrm{OO}^{1}$. 
Traverse-PP ${ }^{1}$ indicates its traverse in E-W direction nearly $850 \mathrm{~m}$ in length approximately middle portion of the study area and it starts from one edge of the road of Landscape Garden, exactly opposite to O.U Library - inside the Landscape Garden - through Forest (adjacent to Tagore Auditorium) - to edge of the Maneru Hostel road.

Figure: 20(a) shows the anomaly response of real and imaginary Fraser filtered data, the percentage ranged from $150 \%$ to $100 \%$.

Figure: 20 (b) shows several closures and pockets of features of conductive bodies at varying degree of conductivity between stations $640 \mathrm{~m}$ and $710 \mathrm{~m}$, a highly conductive body at an approximate depth of $70 \mathrm{~m}$ is indicated. Similarly, between stations $350 \mathrm{~m}$ and $425 \mathrm{~m}$, a linear highly conducive body is indicated. Figure: 20 (a) reveals a number of anomalies, which reflects conductive subsurface structural trends of inferred fractures zones (at $700 \mathrm{~m}$ ) along the traverse.

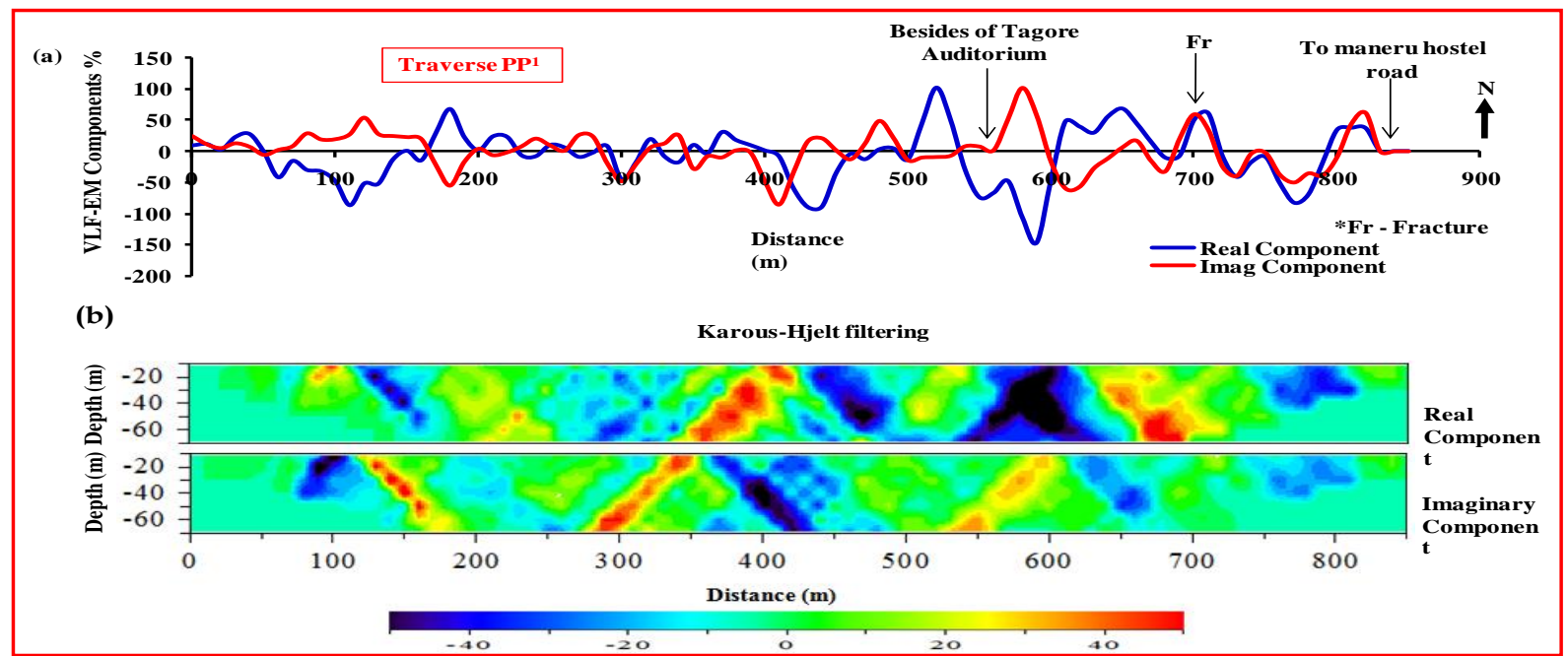

Figure 20 (a), (b):- Fraser filtering graph and equivalent current density pseudo-section of TraversePP ${ }^{1}$.

Traverse- $\mathbf{Q Q}^{\mathbf{1}}$ indicates the path in E-W direction all along the $810 \mathrm{~m}$ length to above middle of the study area and it starts from a junction road after Central Workshop, UCS - Botany and Zoology Departments - to towards to Arts College road.

Figure: 21 (a) shows the Fraser filtered data of in-phase and quadrature component, responses ranged in value from $-110 \%$ to $135 \%$ along the traverse.

Figure: 21(b) shows a major conductive body cross-cut between stations $320 \mathrm{~m}$ and $460 \mathrm{~m}$ forming V-shaped conductive body. Similarly, between stations $190 \mathrm{~m}$ and $300 \mathrm{~m}$, a linear major conductive body is indicated. Generally, the section shows several closures of conductive bodies at different depths. Figure: 21(a) reveals a number of anomalies, which reflects conductive subsurface structural trends of inferred fractures zones (at 170, 250 and $460 \mathrm{~m}$ ) along the traverse. 


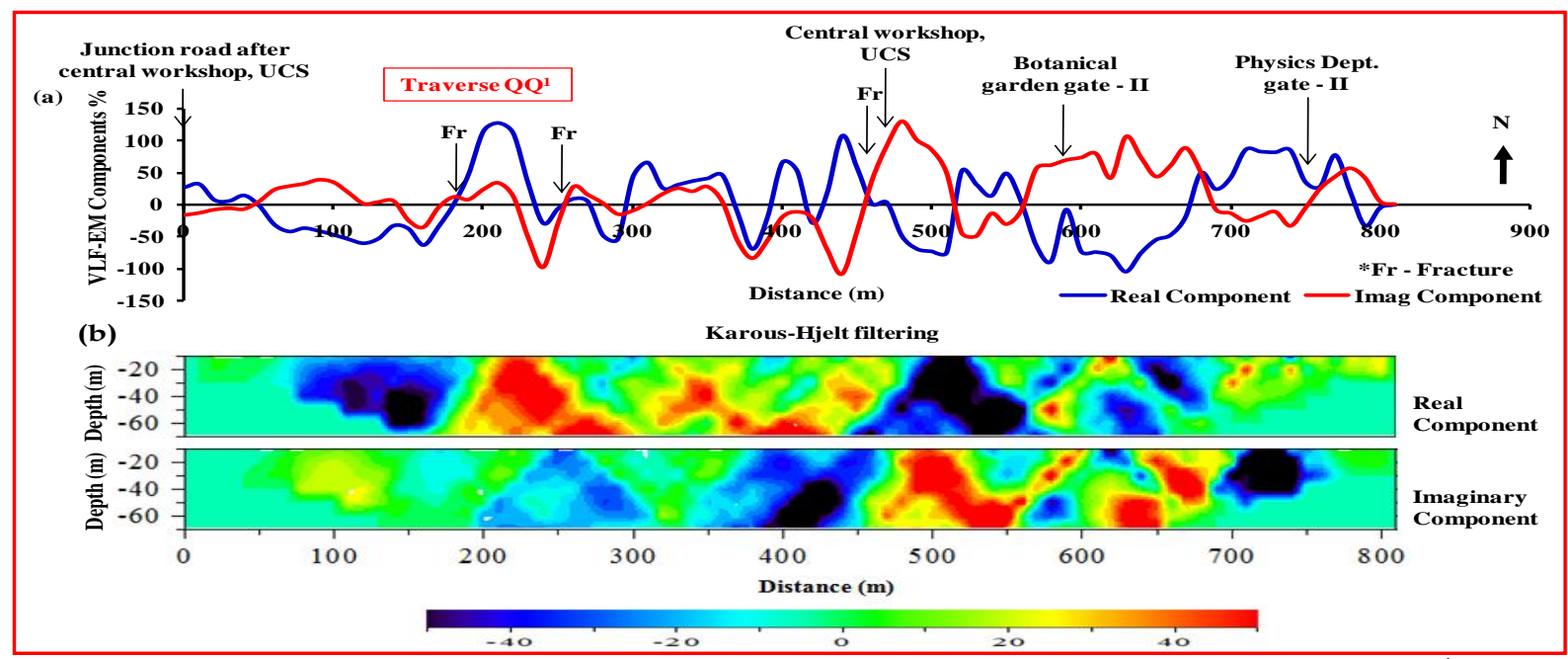

Figure 21 (a), (b):- Fraser filtering graph and equivalent current density pseudo-section of Traverse $\mathrm{QQ}^{1}$.

Traverse- $-\mathbf{R R}^{1}$ is E-W with a trending, $1400 \mathrm{~m}$ long traverse lies to the north part of the study area and it starts from opposite to Directorate Admissions - Post Office - 'B' Hostel - Swimming Pool - to Professors Quarters.

Figure: 22 (a) shows the values ranged from $-270 \%$ to $290 \%$ is the real and imaginary component response of Fraser filtered data.

In Figure: 22(b) different features of varying degree of conductivities are delineated on the section, for instance, between stations $40 \mathrm{~m}$ and $85 \mathrm{~m}, 895 \mathrm{~m}$ and $960 \mathrm{~m}, 1055 \mathrm{~m}$ and $1135 \mathrm{~m}$ at an approximate depth of $32 \mathrm{~m}, 70 \mathrm{~m}$ and $65 \mathrm{~m}$ respectively. Similarly, between stations $250 \mathrm{~m}$ and $320 \mathrm{~m}$, a conductive body at an approximate depth of $60 \mathrm{~m}$ is indicated. Several other closures of conductive bodies are present on the section. Figure: 22(a) reveals a number of anomalies, which reflects conductive subsurface structural trends of inferred fractures zones (at 240, 300, 600, 950, 1060 and $1280 \mathrm{~m}$ ) along the traverse.

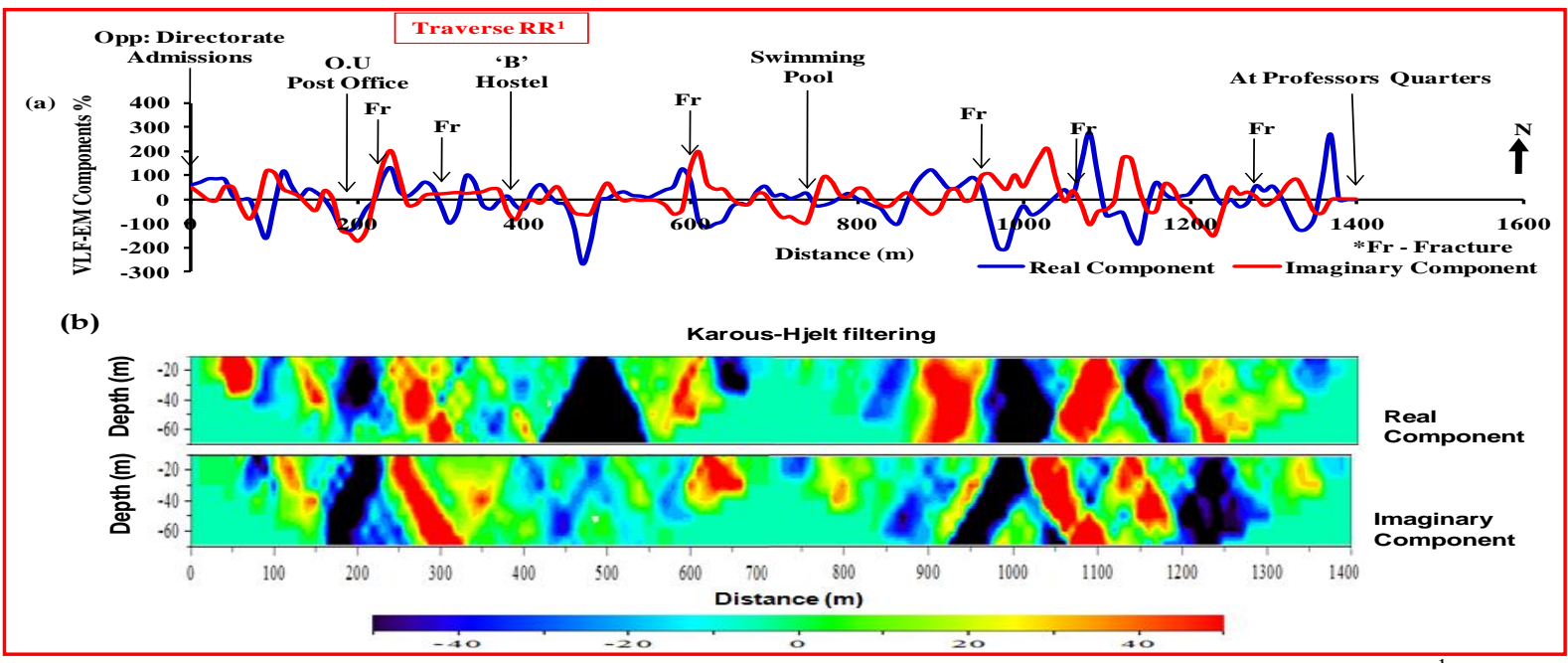

Figure 22 (a), (b):- Fraser filtering graph and equivalent current density pseudo-section of Traverse $\mathrm{RR}^{1}$.

Traverse- $\mathbf{S S}^{\mathbf{1}}$ is nearby Shivalayam adjacent to RTC Hospital - Manjeera Hostel - Bhagirathi Hostel - Basket Ball Court - to Indoor Stadium, running a total length of $590 \mathrm{~m}$ to the North of study area.

Figure: 23 (a) reveals the percentage of anomaly response of real and imaginary Fraser filtered data ranged from $185 \%$ to $210 \%$. 
Figure: 23(b) shows a linear highly conductive body between stations $195 \mathrm{~m}$ and $260 \mathrm{~m}$, at an approximate depth of $65 \mathrm{~m}$. Similarly a Major conductive body indicated on this section between stations $500 \mathrm{~m}$ and $555 \mathrm{~m}$, at an approximate depth of $32 \mathrm{~m}$ is indicated. Figure: 23(a) reveals a number of anomalies, which reflects conductive subsurface structural trends of inferred fractures zones (at 240 and $510 \mathrm{~m}$ ) along the traverse.

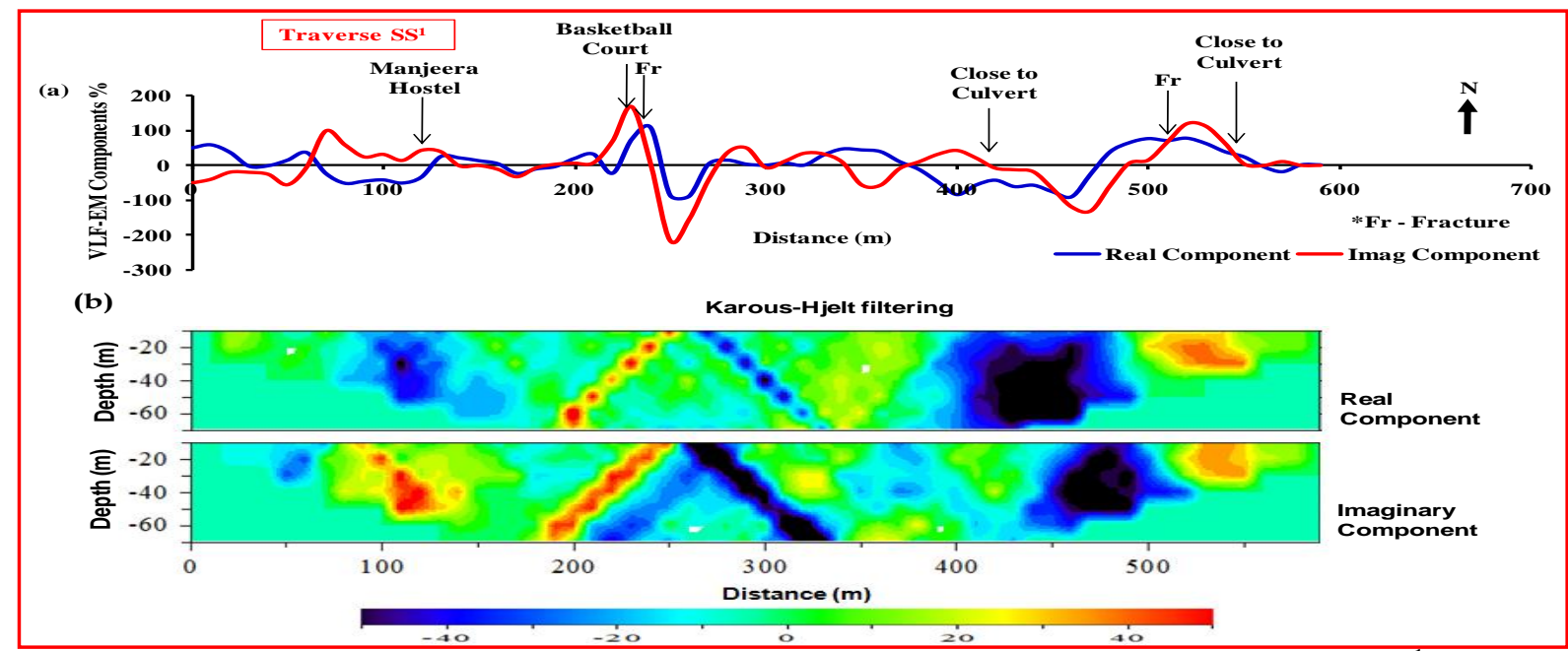

Figure: 22(a), (b) Fraser filtering graph and equivalent current density pseudo-section of Traverse $\mathrm{SS}^{1}$. 
Table: 1 Summary of the VLF-EM Method, subsurface fracture details in the study area.

\begin{tabular}{|c|c|c|c|c|c|c|c|c|}
\hline $\begin{array}{l}\text { S. } \\
\text { No. }\end{array}$ & Traverse & Direction & $\begin{array}{l}\text { Total } \\
\text { Length } \\
(\mathrm{m})\end{array}$ & $\begin{array}{l}\text { Width of the } \\
\text { Body along } \\
\text { the traverse }\end{array}$ & $\begin{array}{c}\text { Depth } \\
\text { (m) }\end{array}$ & Conductive & $\begin{array}{c}\text { Fractures } \\
\text { along } \\
\text { traverse }\end{array}$ & Remarks \\
\hline 1 & \multirow{3}{*}{$\mathrm{AA}^{\prime}$} & \multirow{3}{*}{$\mathrm{N}-\mathrm{S}$} & \multirow{3}{*}{2000} & $\begin{array}{l}590 \mathrm{~m} \text { and } \\
710 \mathrm{~m}\end{array}$ & 70 & $650 \mathrm{~m}$ conductive & \multirow{3}{*}{$\begin{array}{c}500,640 \\
\text { and } \\
1450 \mathrm{~m}\end{array}$} & \\
\hline 2 & & & & $\begin{array}{c}1400 \mathrm{~m} \text { and } \\
1490 \mathrm{~m}\end{array}$ & 70 & $1445 \mathrm{~m}$ conductive & & \\
\hline 3 & & & & & & $1690 \mathrm{~m}$ dyke & & \\
\hline 4 & \multirow{2}{*}{$\mathrm{BB}^{\prime}$} & \multirow{2}{*}{$\mathrm{N}-\mathrm{S}$} & \multirow{2}{*}{2200} & $\begin{array}{c}515 \mathrm{~m} \text { and } \\
620 \mathrm{~m}\end{array}$ & 60 & $\begin{array}{l}565 \mathrm{~m} \text { low } \\
\text { conductive }\end{array}$ & \multirow{2}{*}{$\begin{array}{c}490 \text { and } \\
1850 \mathrm{~m}\end{array}$} & \\
\hline 5 & & & & $\begin{array}{c}1735 \mathrm{~m} \text { and } \\
1890 \mathrm{~m}\end{array}$ & 70 & $1810 \mathrm{~m}$ conductive & & \\
\hline 6 & \multirow{4}{*}{$\mathrm{CC}^{\prime}$} & \multirow{4}{*}{$\mathrm{N}-\mathrm{S}$} & \multirow{4}{*}{2400} & & & $1015 \mathrm{~m}$ conductive & \multirow{4}{*}{$\begin{array}{c}1470 \text { and } \\
2070 \mathrm{~m}\end{array}$} & \\
\hline 7 & & & & $\begin{array}{c}1400 \mathrm{~m} \text { and } \\
1510 \mathrm{~m}\end{array}$ & & $1455 \mathrm{~m}$ conductive & & \\
\hline 8 & & & & & & $1900 \mathrm{~m}$ dyke & & \\
\hline 9 & & & & $\begin{array}{c}2035 \mathrm{~m} \text { and } \\
2170\end{array}$ & & $2100 \mathrm{~m}$ conductive & & \\
\hline 10 & \multirow{3}{*}{$\mathrm{DD}^{\prime}$} & \multirow{3}{*}{$\mathrm{N}-\mathrm{S}$} & \multirow{3}{*}{2430} & $\begin{array}{l}1920 \mathrm{~m} \text { and } \\
2045\end{array}$ & & 1980m conductive & \multirow{3}{*}{$\begin{array}{c}1350, \\
1950 \\
\text { and } \\
2200 \mathrm{~m}\end{array}$} & \\
\hline 11 & & & & $2085 \mathrm{~m} 2190$ & & $2140 \mathrm{~m}$ conductive & & \\
\hline 12 & & & & & & $1820 \mathrm{~m}$ dyke & & \\
\hline 13 & \multirow{3}{*}{$\mathrm{EE}^{\prime}$} & \multirow{3}{*}{$\mathrm{N}-\mathrm{S}$} & \multirow{3}{*}{920} & $\begin{array}{c}220 \mathrm{~m} \text { and } \\
330 \mathrm{~m}\end{array}$ & 70 & $260 \mathrm{~m}$ conductive & \multirow{3}{*}{$\begin{array}{c}70,300 \\
\text { and } \\
370 \mathrm{~m}\end{array}$} & \\
\hline 14 & & & & $\begin{array}{l}280 \mathrm{~m} \text { and } \\
440 \mathrm{~m}\end{array}$ & 70 & $310 \mathrm{~m}$ conductive & & \\
\hline 15 & & & & $490 \mathrm{~m}$ & & dyke & & $\begin{array}{l}\text { NE-SW } \\
\text { Dipping }\end{array}$ \\
\hline 16 & \multirow{5}{*}{$\mathrm{FF}^{\prime}$} & \multirow{5}{*}{ E-W } & \multirow{5}{*}{920} & & & $150 \mathrm{~m} \& 270 \mathrm{~m}$ fault & \multirow{5}{*}{$\begin{array}{c}270,390 \\
\text { and } \\
500 \mathrm{~m}\end{array}$} & \\
\hline 17 & & & & & & 330m dyke & & \\
\hline 18 & & & & $\begin{array}{c}360 \mathrm{~m} \text { and } \\
410 \mathrm{~m}\end{array}$ & 50 & $390 \mathrm{~m}$ conductive & & \\
\hline 19 & & & & & & 440m dyke & & \\
\hline 20 & & & & & & $490 \mathrm{~m}$ conductive & & $\begin{array}{l}\text { NW-SE } \\
\text { Dipping }\end{array}$ \\
\hline 21 & \multirow{3}{*}{ GG' } & \multirow{3}{*}{ E-W } & \multirow{3}{*}{960} & & & $225 \mathrm{~m}$ dyke & \multirow{3}{*}{$\begin{array}{c}300,440 \\
\text { and } 720 \mathrm{~m}\end{array}$} & \\
\hline 22 & & & & $\begin{array}{c}340 \mathrm{~m} \text { and } \\
490 \mathrm{~m}\end{array}$ & 70 & $415 \mathrm{~m}$ conductive & & \\
\hline 23 & & & & $\begin{array}{c}795 \mathrm{~m} \text { and } \\
850 \mathrm{~m}\end{array}$ & 60 & $820 \mathrm{~m}$ conductive & & \\
\hline 24 & $\mathrm{HH}^{\prime}$ & $\mathrm{N}-\mathrm{S}$ & 490 & $\begin{array}{c}215 \mathrm{~m} \text { and } \\
350 \mathrm{~m}\end{array}$ & $\begin{array}{c}\text { above } \\
70 \\
\end{array}$ & $280 \mathrm{~m}$ Fault & $270 \mathrm{~m}$ & \\
\hline 25 & \multirow{6}{*}{ II' } & & & $\begin{array}{l}150 \mathrm{~m} \text { and } \\
220 \mathrm{~m}\end{array}$ & 30 & $185 \mathrm{~m}$ conductive & & $\begin{array}{l}\text { SE-NW } \\
\text { Dipping }\end{array}$ \\
\hline 26 & & & & $\begin{array}{c}165 \mathrm{~m} \text { and } \\
240 \mathrm{~m}\end{array}$ & $\begin{array}{c}\text { above } \\
70\end{array}$ & $205 \mathrm{~m}$ conductive & & \\
\hline 27 & & E-W & 560 & $\begin{array}{c}220 \mathrm{~m} \text { and } \\
265 \mathrm{~m}\end{array}$ & 45 & $240 \mathrm{~m}$ conductive & $\begin{array}{l}170,230 \\
410,450\end{array}$ & $\begin{array}{l}\text { NE-SW } \\
\text { Dipping }\end{array}$ \\
\hline 28 & & & & & & $365 \mathrm{~m}$ Dyke & and $530 \mathrm{~m}$ & \\
\hline 29 & & & & $\begin{array}{l}415 \mathrm{~m} \text { and } \\
500 \mathrm{~m}\end{array}$ & $55 \mathrm{~m}$ & $460 \mathrm{~m}$ conductive & & \\
\hline 30 & & & & $\begin{array}{l}525 \mathrm{~m} \text { and } \\
550 \mathrm{~m}\end{array}$ & $20 \mathrm{~m}$ & $540 \mathrm{~m}$ conductive & & \\
\hline
\end{tabular}




\begin{tabular}{|c|c|c|c|c|c|c|c|c|}
\hline 31 & \multirow{4}{*}{$J^{\prime}$} & \multirow{4}{*}{ E-W } & \multirow{4}{*}{760} & $50 \mathrm{~m}$ and $80 \mathrm{~m}$ & 20 & $65 \mathrm{~m}$ conductive & \multirow{4}{*}{$\begin{array}{c}60,190, \\
350 \text { and } \\
440 \mathrm{~m}\end{array}$} & \multirow[b]{3}{*}{$\begin{array}{l}\text { NE-SW } \\
\text { Dipping }\end{array}$} \\
\hline 32 & & & & $\begin{array}{c}185 \mathrm{~m} \text { and } \\
260 \mathrm{~m}\end{array}$ & 70 & $220 \mathrm{~m}$ conductive & & \\
\hline 33 & & & & & 60 & $380 \mathrm{~m}$ conductive & & \\
\hline 34 & & & & & & $\begin{array}{c}440 \mathrm{~m} \text { and } 510 \mathrm{~m} \\
\text { Fault }\end{array}$ & & \\
\hline 35 & \multirow{3}{*}{ KK' } & \multirow{3}{*}{$\mathrm{E}-\mathrm{W}$} & \multirow{3}{*}{730} & $\begin{array}{l}300 \mathrm{~m} \text { and } \\
400 \mathrm{~m}\end{array}$ & & 350m Fault & \multirow{3}{*}{$\begin{array}{l}300,500 \\
\text { and } 710 \mathrm{~m}\end{array}$} & \\
\hline 36 & & & & $\begin{array}{l}465 \mathrm{~m} \text { and } \\
550 \mathrm{~m}\end{array}$ & & $510 \mathrm{~m}$ conductive & & \\
\hline 37 & & & & $\begin{array}{l}690 \mathrm{~m} \text { and } \\
740 \mathrm{~m}\end{array}$ & 30 & $715 \mathrm{~m}$ conductive & & \\
\hline 38 & LL' $^{\prime}$ & E-W & 790 & $\begin{array}{l}345 \mathrm{~m} \text { and } \\
470 \mathrm{~m}\end{array}$ & 70 & $410 \mathrm{~m}$ conductive & $\begin{array}{l}410 \text { and } \\
490 \mathrm{~m}\end{array}$ & \\
\hline 39 & MM' & E-W & 560 & & 20 & $\begin{array}{l}230 \mathrm{~m} \text { low } \\
\text { conductive }\end{array}$ & $\begin{array}{c}240 \text { and } \\
250 \mathrm{~m}\end{array}$ & \\
\hline 40 & \multirow{3}{*}{$\mathrm{NN}^{\prime}$} & \multirow{3}{*}{ E-W } & \multirow{3}{*}{1560} & & & 595m Dyke & \multirow{3}{*}{$\begin{array}{l}700 \text { and } \\
1200 \mathrm{~m}\end{array}$} & \\
\hline 41 & & & & $\begin{array}{l}640 \mathrm{~m} \text { and } \\
720 \mathrm{~m}\end{array}$ & 50 & $680 \mathrm{~m}$ conductive & & \\
\hline 42 & & & & $\begin{array}{l}900 \mathrm{~m} \text { and } \\
1000 \mathrm{~m}\end{array}$ & 70 & $950 \mathrm{~m}$ conductive & & \\
\hline 43 & $\mathrm{OO}^{\prime}$ & E-W & 440 & $\begin{array}{c}220 \mathrm{~m} \text { and } \\
305 \mathrm{~m}\end{array}$ & 70 & $\begin{array}{l}270 \mathrm{~m} \text { low } \\
\text { conductive }\end{array}$ & $\begin{array}{l}70 \text { and } \\
330 \mathrm{~m}\end{array}$ & $\begin{array}{l}\text { NE-SW } \\
\text { Dipping }\end{array}$ \\
\hline 44 & $\mathrm{PP}^{\prime}$ & $\mathrm{E}-\mathrm{W}$ & 850 & $\begin{array}{l}350 \mathrm{~m} \text { and } \\
400 \mathrm{~m}\end{array}$ & & 375m Fault & $700 \mathrm{~m}$ & \\
\hline 45 & \multirow{4}{*}{$\mathrm{QQ}^{\prime}$} & \multirow{4}{*}{ E-W } & \multirow{4}{*}{810} & $\begin{array}{c}190 \mathrm{~m} \text { and } \\
300 \mathrm{~m}\end{array}$ & & $245 \mathrm{~m}$ conductive & \multirow{4}{*}{$\begin{array}{l}170,250 \\
\text { and } 460 \mathrm{~m}\end{array}$} & \\
\hline 46 & & & & $\begin{array}{l}310 \mathrm{~m} \text { and } \\
390 \mathrm{~m}\end{array}$ & & $350 \mathrm{~m}$ conductive & & $\begin{array}{l}\text { NW-SE } \\
\text { Dipping }\end{array}$ \\
\hline 47 & & & & $\begin{array}{l}390 \mathrm{~m} \text { and } \\
460 \mathrm{~m}\end{array}$ & & $425 \mathrm{~m}$ conductive & & $\begin{array}{l}\text { NE-SW } \\
\text { Dipping }\end{array}$ \\
\hline 48 & & & & & & 740m Lineament & & \\
\hline 49 & \multirow{5}{*}{$\mathrm{RR}^{\prime}$} & \multirow{5}{*}{ E-W } & \multirow{5}{*}{1400} & $40 \mathrm{~m}$ and $80 \mathrm{~m}$ & 35 & $60 \mathrm{~m}$ conductive & \multirow{5}{*}{$\begin{array}{c}240,300, \\
600, \\
950,1060 \\
\text { and } \\
1280 \mathrm{~m}\end{array}$} & \\
\hline 50 & & & & & & 495m Dyke & & \\
\hline 51 & & & & $\begin{array}{l}900 \mathrm{~m} \text { and } \\
960 \mathrm{~m}\end{array}$ & 70 & 930m conductive & & \\
\hline 52 & & & & & & 1000m Dyke & & \\
\hline 53 & & & & $\begin{array}{c}1050 \mathrm{~m} \text { and } \\
1135 \mathrm{~m}\end{array}$ & 65 & $1095 \mathrm{~m}$ conductive & & \\
\hline 54 & \multirow[b]{2}{*}{$\mathrm{SS}^{\prime}$} & \multirow[b]{2}{*}{$\mathrm{N}-\mathrm{S}$} & \multirow[b]{2}{*}{590} & & & 260m Lineament & \multirow[b]{2}{*}{$\begin{array}{l}240 \text { and } \\
510 \mathrm{~m}\end{array}$} & \\
\hline 55 & & & & $\begin{array}{l}500 \mathrm{~m} \text { and } \\
560 \mathrm{~m}\end{array}$ & & $\begin{array}{l}\text { 530m low } \\
\text { conductive }\end{array}$ & & \\
\hline
\end{tabular}

\section{Discussions:-}

Very Low Frequency Electromagnetic (VLF-EM) survey has been conducted for the purpose of delineating subsurface features in the study area, Osmania University campus. A total of nineteen (19) VLF - EM profiles are acquired using ABEM WADI VLF instrument at every 10m interval.

The VLF-EM result mapped shallow linear conductors that are suspected fracture zones of varying length in the area.

The VLF electromagnetic traversing data are presented as plots of filtered real and filtered imaginary (in \%) against station position. VLF -EM traverses from the study area are shown in Figure 4.5(a) to 4.23(a) and these shows the 
linearly filtered real and imaginary components of the vertical magnetic field of the VLF data. Figures 4.5 (b) to 4.23 (b) shows a comparison of the Karous-Hjelt filtered real component (Karous and Hjelt, 1983 ${ }^{[12]}$ ).

The real and imaginary components enable qualitative identification of the top of linear features i.e., points of coincident of crossovers and positive peaks of the real and filtered anomaly. From these plots (Figures 4.5 (a) 4.23(a)), minor linear features suspected to be faults/fractured zones were identified. These suspected geological interfaces and 52 fractures are shown in the table: 4.1, delineated from the profiles, were shown occurring at varying distances on the traverses. These positive peaks mapped as basement fractures (52)/conductive bodies on the filtered real are zones of interest in groundwater exploration in hardrock terrain. The asymmetry of these conductive anomalies suggests that the conductive structures are dipping. Also, the anomaly patterns exhibit varying amplitudes, which are controlled by the depth of the body to the surface, its geometry, and attitude.

Figures (from 3(b) to 21(b)) show the corresponding KH filter pseudo sections of traverses AA ${ }^{1}-S^{1}$. These pseudo sections are the measure of the conductivity of the subsurface as the function of depth. The conductivity is shown as color codes. Different features of varying degree of conductivity trending in different directions were delineated on the sections.

\section{Acknowledgment:-}

The authors gratefully acknowledge the financial support extended by the UGC, New Delhi for granting Emeritus fellow.

\section{References:-}

1. Satpathy, B.N. and Kanungo, B.N. 1976. Groundwater Exploration in Hard-Rock Terrain: A Case Study. Geoph. Prosp. 24(4) pp. 725-736.

2. G.O.Omosuyi . A.O. Adegoke . A.O. Adelusi. 2008. Interpretation of Electromagnetic and Geoelectric Sounding Data for Groundwater Resources around Obanla - Obakekere, near Akure, Southwestern Nigeria. Vol.9. No.2. pp. $509-525$.

3. Oluwafemi, O and Oladunjoye, M.A. 2013. Integration of Surface Electrical and Electromagnetic Prospecting Methods for Mapping Overburden Structures in Akungba - Akoko, Southwestern Nigeria. International Journal of Science and Technology. Vol.2. No.1. pp. 122-147.

4. Hazel, J.R.T., Cratchley, C.R. and Preston, A.M.1988. The Location of Aquifer in Crystalline Rocks and Alluvium in Northern Nigeria using Combined Electromagnetic and Resistivity Techniques. Quarterly Journal of Engineering Geology and Hydrogeology. London. Vol.21, pp. 159 - 175.

5. Paterson, N.R. and Ronka, V., 1971. Five years of surveying with very low frequency electromagnetic method Geoexploration. Vol.9, pp. 7 - 26.

6. Pedersen, L.B., 2002. Measurements with the VLF instrument. Technical Short Note.Department of Earth Sciences, Uppsala University.

7. Sundararajan N and Srinivas Y $1996^{[14]}$, A modified Hilbert transform and its applications to self potential interpretations. Journal of Applied Geophysics 36: 137-143

8. Balakrishna S. and Raghava Rao M., 1961. Pink and grey granites Hyderabad, Current Science, Vol.30, pp.264.

9. Sitaramayya S., 1968. Structure, Petrology and Geochemistry of Granites of Ghatkesar, A.P., and Ph.D. Thesis (unpublished), Osmania University.

10. Sitaramayya S., 1971. The Pyroxene Bearing Granodiorite and Granites of Hyderabad Area, (the Osmania Granites): Quarterly Journal of the Geological, Mining and Metallurgical Society of India, V.43, pp.117-129.

11. Udaya Laxmi and Ramadass 2013, Environmental studies \& Groundwater Quality Assessment Approach through integrated studies in parts of Hyderabad, A.P, India, International Journal of Advances in science and technology Vol.6, No.4, 2013, pp 85-102.

12. Karous, M. R. and Hjelt, S. E. 1983. Linear Filtering of VLF Dip Angle Measurements. Geophysical Prospecting, Vol. 31, pp. $782-794$.

13. Ogilvi RD, Lee AC (1991) Interpretation of VLF-EM in-phase data using current density pseudo-sections. Geophysical Prospecting, Vol 39, pp: 567-580.

14. Fraser D.C, 1969, Contouring of VLF-EM data: Geophysics, Vol. 34, No. 6, p. 958- 967.

15. Wright, J.L. 1988, VLF Interpretation manual: Scintrex. Ltd. 